\title{
Alteration at the ultramafic-hosted Logatchev hydrothermal field: Constraints from trace element and $\mathrm{Sr}-\mathrm{O}$ isotope data
}

\author{
N. Augustin \\ GEOMAR, Helmboltz Centre for Ocean Research Kiel, Wischhofstr. 1-3, D-24148 Kiel, Germany \\ (naugustin@geomar.de)
}

\section{H. Paulick}

Steinmann Institut für Geologie, Mineralogie und Paläontologie, Universität Bonn, Poppelsdorfer Schloss, D-35115 Bonn, Germany

Now at Boliden Mineral AB, Kontorsvägen 1, SE-93631 Boliden, Sweden

K. S. Lackschewitz and A. Eisenhauer

GEOMAR, Helmboltz Centre for Ocean Research Kiel, Wischhofstr. 1-3, D-24148 Kiel, Germany

D. Garbe-Schönberg

Institut für Geowissenschaften, Christian Albrechts Universität Kiel, Ludewig-Meyn Str. 10, D-24118 Kiel, Germany

\section{T. Kuhn}

GEOMAR, Helmboltz Centre for Ocean Research Kiel, Wischhofstr. 1-3, D-24148 Kiel, Germany

Now at BGR, Geozentrum Hannover, Stilleweg 2, D-30655 Hannover, Germany

\section{R. Botz}

Institut für Geowissenschaften, Christian Albrechts Universität Kiel, Ludewig-Meyn Str. 10, D-24118 Kiel, Germany

\section{Schmidt \\ GEOMAR, Helmboltz Centre for Ocean Research Kiel, Wischhofstr. 1-3, D-24148 Kiel, Germany}

[1] Serpentinized peridotite and gabbronorite represent the host rocks to the active, ultramafic-hosted Logatchev hydrothermal field at the Mid-Atlantic Ridge. We use trace element, $\delta^{18} \mathrm{O}$ and ${ }^{87} \mathrm{Sr} /{ }^{86} \mathrm{Sr}$ data from bulk rock samples and mineral separates in order to constrain the controls on the geochemical budget within the Logatchev hydrothermal system. The trace element data of serpentinized peridotite show strong compositional variations indicating a range of processes. Some peridotites experienced geochemical modifications associated with melt-rock interaction processes prior to serpentinization, which resulted in positive correlations of increasing high field strength element (HFSE) concentrations and light rare earth element (LREE) contents. Other serpentinites and lizardite mineral separates are enriched in LREE, lacking a correlation with HFSE due to interaction with high-temperature, black-smoker type fluids. The enrichment of serpentinites and lizardite separates in trace elements, as well as locally developed negative Ce-anomalies, indicate that interaction with low-T ambient seawater is another important process in the Logatchev hydrothermal system. Hence, mixing of high-T hydrothermal fluids during serpentinization and/or re-equilibration of O-isotope signatures during subsequent low-T alteration is required to explain the trace element and $\delta^{18} \mathrm{O}$ temperature 
constraints. Highly radiogenic ${ }^{87} \mathrm{Sr} /{ }^{86} \mathrm{Sr}$ signatures of serpentinite and lizardite separates provide additional evidence for interaction with seawater-derived fluids. Sparse talc alteration at the Logatchev site are most likely caused by Si-metasomatism of serpentinite associated with the emplacement of shallow gabbro intrusion(s) generating localized hydrothermal circulation. In summary the geochemistry of serpentinites from the Logatchev site document subsurface processes and the evolution of a seafloor ultramafic hydrothermal system.

Components: 8800 words, 6 figures, 3 tables.

Keywords: Logatchev hydrothermal field; REE HFSE; hydrothermal alteration; oxygen isotopes; serpentinites; strontium isotopes.

Index Terms: 1032 Geochemistry: Mid-oceanic ridge processes $(3614,8416)$; 1034 Geochemistry: Hydrothermal systems (0450, 3017, 3616, 4832, 8135, 8424); 1065 Geochemistry: Major and trace element geochemistry.

Received 30 September 2011; Revised 18 January 2012; Accepted 30 January 2012; Published 17 March 2012.

Augustin, N., H. Paulick, K. S. Lackschewitz, A. Eisenhauer, D. Garbe-Schönberg, T. Kuhn, R. Botz, and M. Schmidt (2012), Alteration at the ultramafic-hosted Logatchev hydrothermal field: Constraints from trace element and Sr-O isotope data, Geochem. Geophys. Geosyst., 13, Q0AE07, doi:10.1029/2011GC003903.

Theme: From the Mantle to the Ocean: Life, Energy, and Material Cycles at Slow Spreading Ridges

\section{Introduction}

[2] The production of new oceanic crust at midocean ridges drives hydrothermal circulation, which is important for Earth's heat budget [Stein and Stein, 1994] and the chemical composition of the oceans [Edmond et al., 1979a, 1979b; Alt, 1995; Vils et al., 2008]. Along slow-spreading ridges, like the Mid Atlantic Ridge (MAR) there are pronounced variations in the rate of magma production. Commonly, the portions of ridge segments proximal to fracture zones are magma-starved causing thinned crust and the development of prominent extensional faulting. The development of large scale detachment faults leads to significant cooling of the crust [Tucholke and Lin, 1994] and to exposure of mantle peridotites on the seafloor. This process is particularly common at ridges with spreading rates $<20 \mathrm{~mm} \mathrm{a}^{-1}$, which account for about $1 / 3$ of the global 55,000 km long ocean ridge systems [Dick et al., 2003, 2008; Mével, 2003; Smith et al., 2008; Michael et al., 2003].

[3] Hence, ultramafic rocks are an important component of the oceanic lithosphere along slow- and ultra-slow spreading ridges (e.g., MAR, Gakkel Ridge, southwest Indian Ridge). Geochemical, isotopic and textural investigations show that the petrological evolution of depleted mantle domains during ascent in the ridge axis environment includes processes such as melt segregation and channeling, shearing due to mantle flow, refertilization during melt-rock interaction and emplacement of gabbro bodies at various scales [e.g., Dilek et al., 2000]. Furthermore, abyssal peridotites are generally serpentinized as a result of fluid-rock interaction that may occur over a wide range of temperature conditions (from 350 to $400^{\circ} \mathrm{C}$ to ambient seawater temperatures of about $3^{\circ} \mathrm{C}$ ) and influences the physical properties and chemical composition of the oceanic lithosphere [Dick, 1989; Humphris et al., 2003; Bach et al., 2004; Snow and Dick, 1995].

[4] In this study, we present data from the active ultramafic-hosted Logatchev hydrothermal field (LHF) which is located at a slow-spreading segment of the MAR south of the $15^{\circ} 20^{\prime}$ Fracture Zone (Figure 1). This area is characterized by extensive seafloor exposures of lower crust and upper mantle rocks [Cannat et al., 1992, 1997; Rona et al., 1987; Bach et al., 2004; Kelemen et al., 2007]. The LHF is located at $14^{\circ} 45^{\prime} \mathrm{N}, 44^{\circ} 59^{\prime} \mathrm{W}$ on the eastern flank of the rift valley walls and was discovered in 1993 [Batuyev et al., 1994]. General features of this hydrothermal field are described by Cherkashev et al. [2000] and others [Bogdanov et al., 2004; Gablina et al., 2000; Gebruk et al., 2000]. Petersen et al. [2009] summarize results of recent investigations conducted between 2004 and 2007 (HYDROMAR cruises I-IV; R/V Meteor and $\mathrm{R} / \mathrm{V}$ Maria $\mathrm{S}$. Merian) including ship-based 


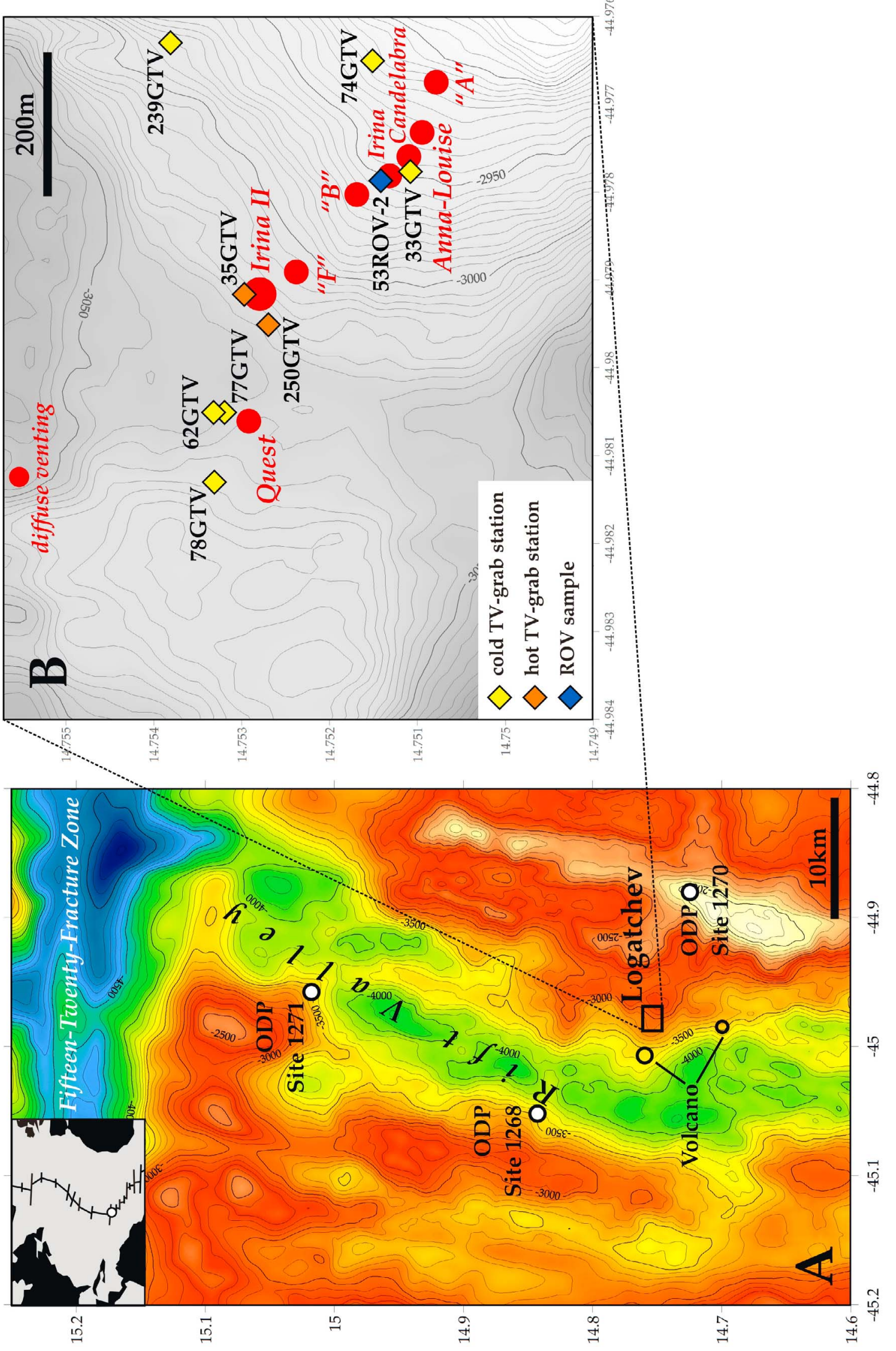

弐 
sampling and deployments of a Remotely Operated Vehicle (ROV).

[5] The principal aims of our research are to elucidate the controlling factors on the geochemical budget of the host-rocks to the LHF, the conditions of fluid/rock reactions, the compositional effects of hydrothermal alteration, and the relative influence of ambient seawater and hydrothermal fluids in the near-seafloor environment. In order to address these questions we present trace element geochemical data, ${ }^{87} \mathrm{Sr} /{ }^{86} \mathrm{Sr}$ and $\delta^{18} \mathrm{O}$ analyses of bulk rock serpentinite and gabbro samples as well as analyses of mineral separates (lizardite, chlorite, and talc).

\section{Geological Setting, Hydrothermal Activity and Alteration at the Logatchev Hydrothermal Field}

[6] The MAR segment adjacent to the $15^{\circ} 20^{\prime}$ Fracture Zone is characterized by abundant faulting which led to the development of a deep rift valley $(>4300 \mathrm{~m})$ flanked by highly segmented walls [Escartín and Cannat, 1999; Fujiwara et al., 2003]. There are abundant outcrops of serpentinite and gabbroic rocks on the eastern and western walls of the ridge axis as well as on the rift valley floor [Petersen et al., 2009]. Volcanic rocks are restricted to local occurrences of pillow basalt lava flows [Petersen et al., 2009].

[7] The LHF is located on a plateau right below a $350 \mathrm{~m}$ high cliff between $3060 \mathrm{~m}$ and $2910 \mathrm{~m}$ water depth $\left(14^{\circ} 45^{\prime} \mathrm{N}, 44^{\circ} 58^{\prime} \mathrm{W}\right)$ on the eastern rift valley flank ca. $7 \mathrm{~km}$ away from the ridge axis (Figure 1). Here, N-S and WNW-ESE striking faults generate a blocky and irregular, terrace-like topography [Petersen et al., 2009]. Two pillow volcanoes were identified at $2 \mathrm{~km}$ west and $5 \mathrm{~km}$ south of the LHF.

[8] Recent mapping of the LHF showed that hydrothermal activity is present in an $800 \mathrm{~m}$ long, NW-SE striking zone [Petersen et al., 2009] (Figure 1). Two distinctive types of structures with high-temperature hydrothermal discharge can be distinguished: (1) black smoker type vents with fluid temperatures up to $330^{\circ} \mathrm{C}$ (Barad-Dûr, Site "A," IRINA II) and (2) so-called "smoking craters" with fluid temperatures up to $360^{\circ} \mathrm{C}$ where hot hydrothermal fluids are discharging from local depressions (sites Anna-Louise, Candelabra, Irina, Site "B" and Quest [Petersen et al., 2009]). In addition, there are sites of diffuse hydrothermal discharge (Site "F" and at the base of Irina II). Endmember compositions of the LHF hydrothermal fluids are characterized by very high concentrations of dissolved methane and hydrogen (up to $3.5 \mathrm{mM}$ and $19 \mathrm{mM}$, respectively) which relate to subsurface serpentinization processes [Douville et al., 2002; Schmidt et al., 2007]. Elevated sub-seafloor temperatures of up to $>100^{\circ} \mathrm{C}$ have been detected immediately below hydrothermal crusts during TV grab sampling in the vicinity of the Irina II black smoker structure (Figure 1).

[9] Based on extensive seafloor observations by camera tows, ROV diving and TV-guided grab sampling it has been established, that the seafloor surrounding the Logatchev vent sites is mainly characterized by pelagic sediment-covered talus of serpentinized peridotite and gabbroic rocks with relative proportions of about 80:20 [Petersen et al., 2009]. Close to the vent sites the sediments are generally hydrothermally altered, covered by hydrothermal crusts and contain highly altered rocks, sulfides, and secondary clay minerals.

[10] The ultramafic rocks in the LHF area are dunites (90-100\% serpentinization) and harzburgites (80 to $90 \%$ serpentinization [Augustin et al., 2008; Petersen et al., 2009]). Relics of coarse orthopyroxene are common in serpentinized harzburgite whereas relics of olivine are rare. Lizardite is the predominant serpentine polymorph with occurrences of chrysotile largely restricted to some veins ([Augustin et al., 2008] X-ray diffraction analysis). Magnetite occurs as fine grains in the matrix or along grain boundaries.

[11] Early talc-tremolite alteration was predicted in thermodynamic models in the work of Klein et al. [2009]. The latter paper describes talc-tremolite alteration of opx in peridotite with fresh olivine and infers alteration temperatures of $>350-400^{\circ} \mathrm{C}$. Augustin et al. [2008] adopted that interpretation.

[12] In contrast to samples recovered from other sites in the $15^{\circ} 20^{\prime} \mathrm{N}$ area by scientific drilling [Kelemen et al., 2007; Bach et al., 2004, 2006] all serpentinite samples from the LHF are devoid of brucite. This, however, is a common phenomenon in abyssal peridotite sampled directly from the seafloor and could be a result of destabilization of brucite in the ambient seawater environment ("seafloor weathering" [Snow and Dick, 1995]).

Figure 1. (a) The bathymetric map is showing the location of the Logatchev hydrothermal field at the Mid-Atlantic ridge. (b) Detailed bathymetry with sampling stations at the active Logatchev hydrothermal field (Table 1). The positions of vent sites are marked with red circles. 


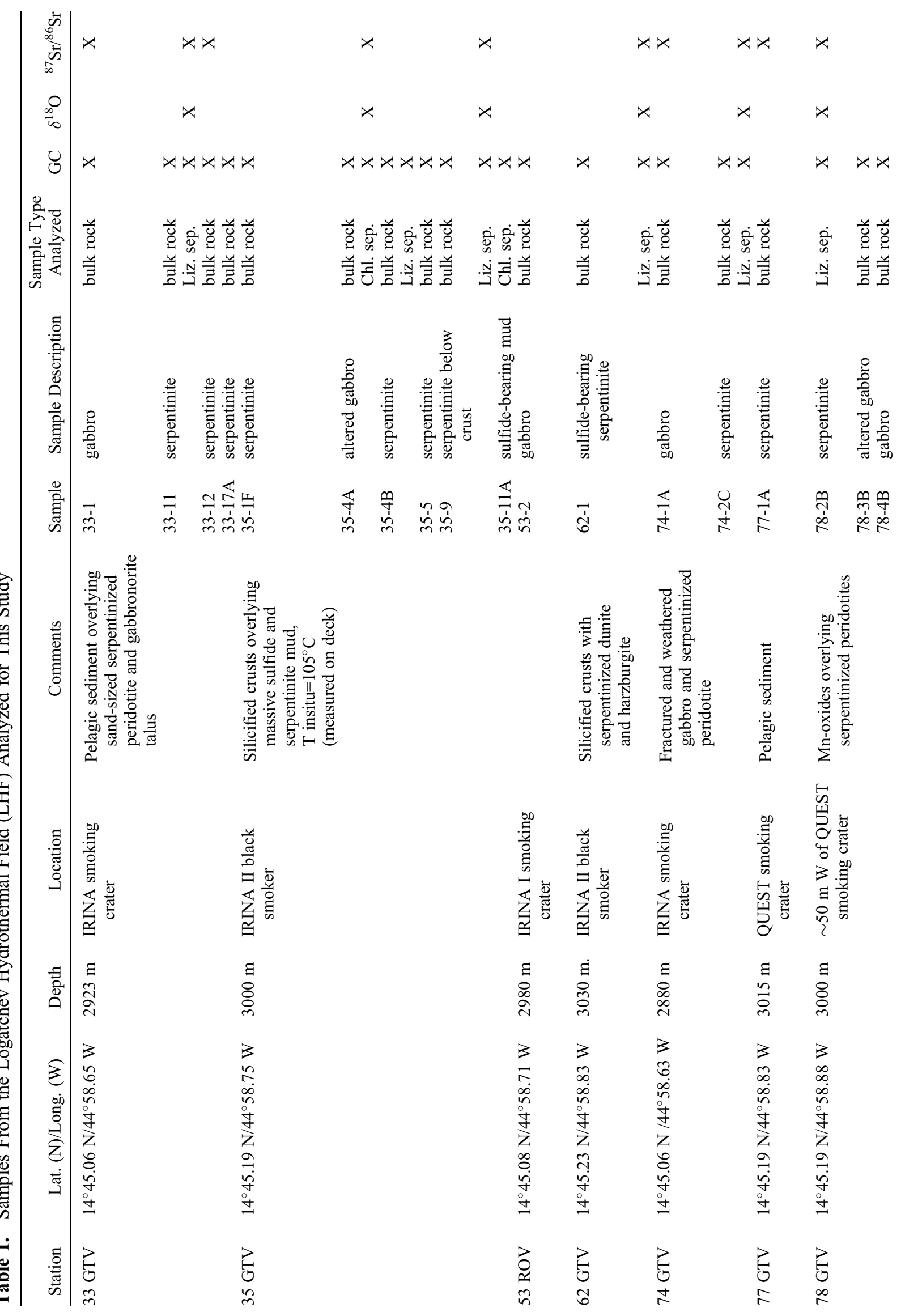


[13] The gabbroic rocks sampled are coarse to medium-grained commonly showing hypidiomorphic pyroxene crystals in a matrix of xenomorphic, granular plagioclase and are classified as gabbronorite [Petersen et al., 2009]. Commonly, hydrothermal alteration is restricted to replacement of pyroxene crystals by chlorite and finely dispersed sulfides. The XRD spectra of chlorite separates show that clinochlore is dominant and locally accompanied by corrensite ([Augustin et al., 2008] $\mathrm{X}$-ray diffraction analysis).

[14] Petrographic observations show sharp contacts between gabbronorite and serpentinites where the serpentine minerals are completely replaced by talc [Augustin et al., 2008; Petersen et al., 2009]. In these cases, $\mathrm{SiO}_{2}(\mathrm{aq})$ released from gabbro during fluid/rock interaction is probably responsible for the transformation of serpentinite to talc rock. Such a scenario is consistent with models suggested for talc alteration of serpentinites at ODP Site 1268 (ODP Leg 209) which involves mobilization of pore water in serpentinites in secondary circulation cells as a consequence of shallow gabbro emplacement [Barnes et al., 2009].

\section{Sample Material and Methods}

\subsection{Samples and Mineral Separation}

[15] Samples for this study were obtained from 8 stations located in the immediate vicinity of black smokers and smoking craters whereas one station (239-GTV) is relatively remote at $300 \mathrm{~m}$ to the NE of the LHF (Figure 1 and Table 1). All samples where obtained by TV-guided grab equipment (GTV) except for one station sampled by a Remotely Operated Vehicle (ROV; Table 1). Two of the TV grab samples retained elevated temperatures during transit through the water column and $\mathrm{T}=105^{\circ} \mathrm{C}(35 \mathrm{GTV})$ and $\mathrm{T}=43^{\circ} \mathrm{C}(250 \mathrm{GTV})$ were measured on deck. At these stations, hydrothermal crusts, acting as seals to the sub-seafloor hydrothermal system, were mechanically penetrated. A quartz fragment from such a crust at site 250 GTV was included in this study for $\delta^{18} \mathrm{O}$ thermometry.

[16] In general, the sampled seafloor material consists of a mixture of brownish to gray pelagic sediment with large amounts of foraminifer shells together with fragments of serpentinized peridotite and gabbronorite in variable proportions. The materials analyzed are bulk rock samples and separates of lizardite from serpentinites and chlorite from gabbronorites. Furthermore, one monomineralic talc rock (239-4A) and one talc separate from 
Table 2. Geochemical Data of LHF Samples ${ }^{\mathrm{a}}$

\begin{tabular}{|c|c|c|c|c|c|c|c|c|c|c|c|c|c|}
\hline Station & Sample & Type & Lithology & $\mathrm{Li}$ & $\mathrm{Sc}$ & V & $\mathrm{Cr}$ & $\mathrm{Co}$ & $\mathrm{Ni}$ & $\mathrm{Cu}$ & $\mathrm{Zn}$ & $\mathrm{Ga}$ & $\mathrm{Rb}$ \\
\hline GTV & 1 & ulk & serpent & 7.8 & 20.1 & 772 & 3013 & 151 & 1326 & 4341 & 1583 & 1.82 & 0.4 \\
\hline TV & & & serne & 4.0 & 7.9 & & 9 & 3.3 & & & 1359 & & 0.20 \\
\hline GTV & $33-17 \mathrm{~A}$ & $\mathrm{llk} \mathrm{r}$ & serpentinite & 27.6 & 33.1 & 142 & 41.1 & 29.1 & 60.7 & 193 & 180 & 12.1 & 6.8 \\
\hline GTV & $35-1 \mathrm{~F}$ & lk rock & serpentinite & 9.7 & 3.6 & 26.7 & 97.0 & 18.8 & 35.8 & 4158 & 1870 & 4.4 & 4.5 \\
\hline $5 \mathrm{GTV}$ & $35-4 \mathrm{~A}$ & lk rock & serpentinite & 17.2 & 11.3 & 75. & 438 & 219 & 312 & 26921 & 391 & 4.3 & 2.5 \\
\hline $5 \mathrm{GTV}$ & $35-4 B$ & llk rock & serpentinite & 8.1 & 8.1 & 19.7 & 67.0 & 9.3 & 35.5 & 84.6 & 145 & 1.89 & 0.57 \\
\hline $5 \mathrm{GTV}$ & & $\mathrm{llk} \mathrm{r}$ & serp & 2.2 & 5.1 & 16.9 & 857 & 48.1 & 1164 & 12 & 229 & 0.45 & 0.25 \\
\hline GTV & & $\mathrm{lk} \mathrm{r}$ & serp & 3.4 & 6.0 & 30.8 & 2407 & 92.3 & 1972 & 12 & 340 & 0.72 & 1.06 \\
\hline GTV & $62-$ & $\mathrm{lk}$ & serp & 3.4 & 8.8 & & 15 & 98.5 & 14 & & 50.5 & & 0.27 \\
\hline GTV & $74-2$ & $\mathrm{lk}$ & serp & 4.0 & 9.2 & 65 & 28 & 125 & 22 & & 63.8 & & 0.17 \\
\hline GTV & $250-$ & $\mathrm{lk}$ & ser & 8 & 36 & 17 & 10 & 1 & 13 & & 16 & & 2.1 \\
\hline TV & & 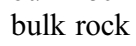 & & & 4 & & & 33 & 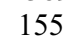 & & 30 & 11 & 0.39 \\
\hline TV & & $\mathrm{llk}$ & & 42.8 & 22.7 & 17 & 17 & 46 & 31 & & $8^{\prime}$ & & 0.30 \\
\hline TV & $74-1 \mathrm{~A}$ & 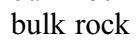 & & 5.1 & 43.8 & 16 & 43 & 40 & 74 & 93 & 53.6 & 12.9 & 0.83 \\
\hline TV & $78-2$ & $1 \mathrm{k}$ & & 51.4 & 35.6 & 16 & 30.4 & 49.8 & 101 & 97 & 50.3 & 11.7 & 0.43 \\
\hline ITV & B & 11 & & - & - & 121 & 105 & 33.0 & 104 & & 32.0 & - & - \\
\hline $0 \mathrm{GTV}$ & $250-4$ & bulk & & 29.1 & 44.6 & 120 & 81 & 62.0 & 19 & & 140 & 16.5 & 1.78 \\
\hline 33 GTV & $33-11$ & separate & & 2.8 & 11.6 & 52.6 & 58 & 107 & 1152 & 70 & 2224 & 0.99 & 0.14 \\
\hline $35 \mathrm{GTV}$ & $35-4 B$ & separate & & 5.9 & 21.2 & 32. & & 14.8 & & & 546 & 2 & 0.14 \\
\hline $35 \mathrm{GTV}$ & & separ & & 3.1 & 7.8 & 26 & 1144 & 92.2 & 1957 & 4 & 981 & 0.64 & 0.32 \\
\hline TV & $-1 \mathrm{~B}$ & & & 3 & 9. & & & 12 & & & 28 & 0.92 & 0.15 \\
\hline $\mathrm{V}$ & $14-2$ & & & 5 & 9. & & 14 & 14 & & & 362 & 2 & 0.27 \\
\hline & & & & & 6 & & & 8 & 1229 & & 29 & & 0.06 \\
\hline & & P & & & 29 & 17 & 13 & & 43 & 14 & 51 & & 0.29 \\
\hline GTV & $35-11 \mathrm{~A}$ & sepa & & 158.3 & 44.8 & 39 & 501 & 59.4 & 66.2 & 97 & 721 & 14.5 & 0.25 \\
\hline $250 \mathrm{GTV}$ & $250-4$ & sepa & chlorite & 41.5 & 80.8 & 15 & 1028 & 56.9 & 205 & & 256 & 20.2 & 6.4 \\
\hline 239 GTV & $239-4 B$ & separate & & 71.0 & 0.23 & 207 & 33.0 & 20.0 & 150 & & 1023 & 4.7 & 0.36 \\
\hline 239 GTV & $239-4 \mathrm{~A}$ & bulk rock & talc fragment & 20.6 & 0.44 & 1.84 & 2.5 & 3.6 & 20.1 & 391.9 & 279 & 2.6 & 0.14 \\
\hline
\end{tabular}

\begin{tabular}{|c|c|c|c|c|c|c|c|c|c|c|c|c|c|c|}
\hline Station & $\mathrm{Sr}$ & $\mathrm{Y}$ & $\mathrm{Zr}$ & $\mathrm{Nb}$ & $\mathrm{Cs}$ & $\mathrm{Ba}$ & $\mathrm{La}$ & $\mathrm{Ce}$ & $\operatorname{Pr}$ & $\mathrm{Nd}$ & $\mathrm{Sm}$ & $\mathrm{Eu}$ & $\mathrm{Gd}$ & $\mathrm{Tb}$ \\
\hline 3 GTV & 7.0 & 0.49 & 1.15 & 0.16 & 0.004 & 3.3 & 0.09 & 0.90 & 0.08 & 0.38 & 0.17 & 0.06 & 0.14 & 0.03 \\
\hline $33 \mathrm{GTV}$ & 3.9 & 0.35 & 0.04 & 0.01 & 0.003 & 0.64 & 0.09 & 0.09 & 0.06 & 0.27 & 0.07 & 0.03 & 0.08 & 0.01 \\
\hline 33 GTV & 177 & 4.9 & 6.4 & 0.35 & 0.72 & 23.1 & 0.87 & 2.1 & 0.33 & 1.70 & 0.57 & 0.43 & 0.76 & 0.14 \\
\hline $35 \mathrm{GTV}$ & 508 & 0.92 & 3.2 & 0.52 & 0.83 & 97.3 & 0.39 & 0.92 & 0.12 & 0.55 & 0.15 & 1.37 & 0.17 & 0.03 \\
\hline 35 GTV & 17.7 & 2.0 & 15.9 & 1.71 & 0.09 & 31.2 & 1.24 & 2.7 & 0.35 & 1.46 & 0.33 & 0.05 & 0.36 & 0.06 \\
\hline $35 \mathrm{GTV}$ & 1631 & 1.71 & 1.91 & 0.10 & 0.03 & 136 & 0.24 & 0.54 & 0.08 & 0.42 & 0.16 & 0.26 & 0.25 & 0.05 \\
\hline $35 \mathrm{GTV}$ & 3.6 & 0.51 & 0.72 & 0.14 & 0.02 & 27.6 & 0.14 & 0.37 & 0.05 & 0.24 & 0.07 & 0.03 & 0.08 & 0.01 \\
\hline $35 \mathrm{GTV}$ & 8.5 & 0.49 & 3.3 & 0.64 & 0.16 & 109 & 0.19 & 0.47 & 0.07 & 0.31 & 0.08 & 0.05 & 0.09 & 0.01 \\
\hline $62 \mathrm{GTV}$ & 1.56 & 0.9 & 0.12 & 0.02 & 0.01 & 0.36 & 0.18 & 0.42 & 0.07 & 0.38 & 0.10 & 0.16 & 0.13 & 0.02 \\
\hline 74 GTV & 4.5 & 0.4 & 0.29 & & 0.0 & & & & 6 & & & & 9 & 0.01 \\
\hline $250 \mathrm{GTV}$ & 45.5 & 3.5 & 7.2 & 0.13 & 0.02 & 6.2 & 0.15 & 0.38 & 0.09 & 0.55 & 0.26 & 0.10 & 0.32 & 0.08 \\
\hline GTV & 180 & 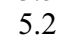 & 5.1 & 0.18 & 0.01 & 14.0 & 0.72 & 1.72 & 0.29 & 1.48 & 0.54 & 0.37 & 0.71 & 0.13 \\
\hline $53 \mathrm{GTV}$ & 76.2 & 6.3 & 6.2 & 1.52 & 0.02 & 5.8 & 2.48 & 3.1 & 0.66 & 2.9 & 0.78 & 0.96 & 0.92 & 0.15 \\
\hline 74 GTV & 166 & 7.7 & 11.1 & 0.97 & 0.02 & 21.0 & 1.30 & 3.0 & 0.47 & 2.4 & 0.82 & 0.51 & 1.08 & 0.20 \\
\hline $78 \mathrm{GTV}$ & 8.6 & 5.2 & 4.2 & 1.17 & 0.03 & 0.59 & 0.63 & 1.87 & 0.31 & 1.53 & 0.55 & 0.26 & 0.71 & 0.13 \\
\hline $78 \mathrm{GTV}$ & - & 4.2 & - & - & - & 12.3 & 0.61 & 1.56 & 0.26 & 1.36 & 0.48 & 0.36 & 0.68 & 0.13 \\
\hline $250 \mathrm{GTV}$ & 96.9 & 4.1 & 6.9 & 0.21 & 0.09 & 7.8 & 0.37 & 1.10 & 0.17 & 0.96 & 0.37 & 0.26 & 0.55 & 0.11 \\
\hline 33 GTV & 17.1 & 0.31 & 13.3 & 0.13 & 0.01 & 22.5 & 0.14 & 1.58 & 0.09 & 0.40 & 0.15 & 0.05 & 0.13 & 0.03 \\
\hline $35 \mathrm{GTV}$ & 1043 & 2.2 & 14.3 & 0.08 & 0.01 & 79.3 & 0.24 & 0.61 & 0.10 & 0.46 & 0.18 & 0.32 & 0.24 & 0.05 \\
\hline $35 \mathrm{GTV}$ & 56.8 & 1.06 & 48.8 & 0.32 & 0.09 & 283 & 0. & 1.73 & 0.15 & 0.63 & 0.16 & 0.03 & 0.17 & 0.03 \\
\hline $62 \mathrm{GTV}$ & & & 19.3 & & & & & & & & & 0.22 & 0.25 & 0.04 \\
\hline 74 GTV & 135 & 1.53 & 31.7 & 0. & & & 0. & 0.71 & 0.28 & 1.22 & & 0.05 & 36 & 0.06 \\
\hline 78 GTV & 171 & 1.40 & 38.0 & 0.08 & 0.004 & 73.2 & 0.86 & 1.17 & 0.21 & 0.67 & 0.12 & - & 0.15 & 0.02 \\
\hline 35 GTV & 81.6 & 4.3 & 46.0 & 2.3 & 0.03 & 20.2 & 1.62 & 3.3 & 0.42 & 1.87 & 0.44 & 0.07 & 0.52 & 0.09 \\
\hline 35 GTV & 9.4 & 19.9 & 92.6 & 7.1 & 0.02 & 14.1 & 41.1 & 94.2 & 9.7 & 34.4 & 5.0 & 0.78 & 3.7 & 0.53 \\
\hline $250 \mathrm{GTV}$ & 19.4 & 3.3 & 17.5 & 0.88 & 0.41 & 10.8 & 1.75 & 6.3 & 0.45 & 2.1 & 0.62 & 0.25 & 0.68 & 0.12 \\
\hline 239 GTV & 21.9 & 8.4 & 7.4 & 0.17 & 0.02 & 19.1 & 3.6 & 1.27 & 0.73 & 3.3 & 0.71 & 1.95 & 0.91 & 0.14 \\
\hline 239 GTV & 11.7 & 1.17 & 4.2 & 0.08 & 0.005 & 1.13 & 0.01 & 0.02 & 0.002 & 0.01 & 0.00 & 0.05 & 0.001 & - \\
\hline
\end{tabular}


Table 2. (continued)

\begin{tabular}{|c|c|c|c|c|c|c|c|c|c|c|c|c|c|c|}
\hline Station & Dy & Ho & $\mathrm{Er}$ & $\mathrm{Tm}$ & $\mathrm{Yb}$ & $\mathrm{Lu}$ & $\mathrm{Hf}$ & $\mathrm{Ta}$ & $\mathrm{Tl}$ & $\mathrm{Pb}$ & $\mathrm{Th}$ & $\mathrm{U}$ & $\mathrm{Eu}_{\mathrm{N}} / \mathrm{Eu}^{*}{ }_{\mathrm{N}}$ & $(\mathrm{La} / \mathrm{Lu})_{\mathrm{N}}$ \\
\hline $33 \mathrm{GTV}$ & 0.22 & 0.04 & 0.11 & 0.02 & 0.16 & 0.02 & 0.02 & 0.01 & 0.02 & 1.53 & 0.01 & 1.75 & 1.18 & 0.43 \\
\hline 33 GTV & 0.08 & 0.01 & 0.04 & 0.01 & 0.04 & 0.01 & 0.00 & 0.003 & 0.01 & 0.70 & 0.00 & 1.88 & 1.17 & 1.21 \\
\hline $33 \mathrm{GTV}$ & 0.95 & 0.20 & 0.55 & 0.08 & 0.56 & 0.08 & 0.23 & 0.03 & 0.01 & 0.25 & 0.03 & 0.23 & 1.98 & 1.10 \\
\hline $35 \mathrm{GTV}$ & 0.21 & 0.05 & 0.13 & 0.02 & 0.14 & 0.02 & 0.11 & 0.04 & - & 162 & 0.16 & 2.8 & 25.86 & 1.95 \\
\hline $35 \mathrm{GTV}$ & 0.47 & 0.12 & 0.38 & 0.07 & 0.49 & 0.08 & 0.73 & 0.19 & 0.41 & 56.8 & 1.85 & 7.6 & 0.44 & 1.61 \\
\hline $35 \mathrm{GTV}$ & 0.32 & 0.07 & 0.19 & 0.03 & 0.18 & 0.03 & 0.07 & 0.03 & 0.26 & 3.1 & 0.03 & 6.1 & 3.89 & 0.90 \\
\hline $35 \mathrm{GTV}$ & 0.09 & 0.02 & 0.05 & 0.01 & 0.06 & 0.01 & 0.02 & 0.01 & 0.07 & 1.53 & 0.01 & 0.18 & 1.41 & 1.57 \\
\hline $35 \mathrm{GTV}$ & 0.09 & 0.02 & 0.06 & 0.01 & 0.06 & 0.01 & 0.09 & 0.04 & 0.01 & 4.5 & 0.04 & 0.27 & 1.75 & 1.93 \\
\hline 62 GTV & 0.11 & 0.02 & 0.06 & 0.01 & 0.07 & 0.01 & 0.00 & 0.00 & 0.41 & 0.77 & 0.00 & 0.44 & 4.09 & 1.56 \\
\hline $74 \mathrm{GTV}$ & 0.09 & 0.02 & 0.05 & 0.01 & 0.06 & 0.01 & 0.01 & 0.01 & 0.02 & 0.80 & 0.01 & 1.43 & 0.94 & 1.66 \\
\hline $250 \mathrm{GTV}$ & 0.45 & 0.10 & 0.29 & 0.05 & 0.37 & 0.05 & 0.04 & 0.09 & - & 3.4 & 0.01 & 4.3 & 1.10 & 0.30 \\
\hline 33 GTV & 0.88 & 0.19 & 0.52 & 0.08 & 0.52 & 0.08 & 0.18 & 0.02 & 0.10 & 0.17 & 0.02 & 0.02 & 1.81 & 0.98 \\
\hline 53 GTV & 1.00 & 0.20 & 0.58 & 0.08 & 0.54 & 0.08 & 0.19 & 0.08 & 0.10 & 1.85 & 0.05 & 10.6 & 3.46 & 3.28 \\
\hline 74 GTV & 1.35 & 0.28 & 0.81 & 0.12 & 0.81 & 0.12 & 0.36 & 0.06 & 0.005 & 0.25 & 0.09 & 0.05 & 1.64 & 1.12 \\
\hline $78 \mathrm{GTV}$ & 0.89 & 0.19 & 0.54 & 0.08 & 0.56 & 0.08 & 0.16 & 0.07 & 0.01 & 0.06 & 0.06 & 0.03 & 1.28 & 0.80 \\
\hline $78 \mathrm{GTV}$ & 0.89 & 0.19 & 0.53 & 0.08 & 0.56 & 0.08 & - & - & - & 0.28 & - & - & 1.93 & 0.79 \\
\hline $250 \mathrm{GTV}$ & 0.70 & 0.16 & 0.45 & 0.06 & 0.40 & 0.05 & 0.20 & 0.05 & - & 0.41 & 0.02 & 1.43 & 1.79 & 0.71 \\
\hline $33 \mathrm{GTV}$ & 0.17 & 0.03 & 0.08 & 0.02 & 0.14 & 0.03 & 0.30 & 0.02 & 0.02 & 5.7 & 0.04 & 1.96 & 0.99 & 0.51 \\
\hline $35 \mathrm{GTV}$ & 0.39 & 0.09 & 0.25 & 0.05 & 0.35 & 0.06 & 0.34 & 0.01 & 0.04 & 4.0 & 0.05 & 9.5 & 4.64 & 0.41 \\
\hline $35 \mathrm{GTV}$ & 0.17 & 0.04 & 0.10 & 0.08 & 0.19 & 0.05 & 1.23 & 0.03 & 0.01 & 10.3 & 0.12 & 0.32 & 0.46 & 0.86 \\
\hline $62 \mathrm{GTV}$ & 0.24 & 0.05 & 0.14 & 0.08 & 0.22 & 0.05 & 0.52 & 0.01 & 0.18 & 5.0 & 0.05 & 0.78 & 2.99 & 0.86 \\
\hline 74 GTV & 0.34 & 0.06 & 0.17 & 0.03 & 0.25 & 0.05 & 0.72 & 0.01 & 0.01 & 4.4 & 0.07 & 1.15 & 0.42 & 1.02 \\
\hline $78 \mathrm{GTV}$ & 0.14 & 0.03 & 0.10 & 0.02 & 0.26 & 0.07 & 0.83 & 0.01 & 0.14 & 5.0 & 0.08 & 1.04 & - & 1.28 \\
\hline 35 GTV & 0.75 & 0.18 & 0.64 & 0.11 & 0.80 & 0.13 & 1.30 & 0.20 & 0.04 & 25.8 & 2.7 & 6.3 & 0.45 & 1.29 \\
\hline $35 \mathrm{GTV}$ & 3.2 & 0.70 & 2.2 & 0.35 & 2.5 & 0.39 & 2.3 & 0.53 & 0.08 & 111 & 11.5 & 24.6 & 0.55 & 10.86 \\
\hline $250 \mathrm{GTV}$ & 0.78 & 0.17 & 0.47 & 0.07 & 0.50 & 0.07 & 0.51 & 0.09 & - & 30.5 & 0.45 & 8.9 & 1.20 & 2.77 \\
\hline $239 \mathrm{GTV}$ & 0.91 & 0.22 & 0.69 & 0.09 & 0.62 & 0.10 & 0.11 & 0.03 & - & 100 & 0.04 & 13.1 & 7.39 & 3.95 \\
\hline 239 GTV & 0.001 & 0.001 & 0.002 & 0.001 & 0.002 & - & 0.04 & 0.04 & - & 0.12 & 0.01 & 4.7 & 89.24 & - \\
\hline
\end{tabular}

${ }^{\mathrm{a}}$ All values in $\mathrm{ppm}$.

sediment (239-4B) were sampled from the distal site $239 \mathrm{GTV}$. One chlorite separate from the sediment fraction of station 35 GTV (sample 35-11A) was analyzed.

[17] During the first step of mineral separation, a fine grain size fraction $(<63 \mu \mathrm{m})$ was obtained from the sediment samples (35-11A and 239-4B) by wet sieving. The rock samples were ground gently in a mortar in order to generate fine material suitable for separating a $<63 \mu \mathrm{m}$ grain size fraction. Subsequent grain size separation into silt $(2-63 \mu \mathrm{m})$ and clay fraction $(<2 \mu \mathrm{m})$ was performed according to Stokes' law by settling the particles in water filled cylinders [Moore and Reynolds, 1989]. The composition of the $<2 \mu \mathrm{m}$ separates was determined by $\mathrm{X}$-ray diffraction (XRD) analysis and the monomineralic composition confirmed at the level of XRD precision at a detection limit for accessory phases of about 3\% [Augustin et al., 2008].

\subsection{Geochemical Analyses}

[18] Geochemical analyses were performed on serpentinized peridotite $(n=11)$, gabbronorite $(n=6)$, lizardite separates $(n=6)$, chlorite separates $(n=3)$ and 2 talc samples (monomineralic bulk rock sample 239-4A and talc mineral separate from sample 239-4B; Table 1). In total, 28 trace element analyses were performed by ICP-MS using a VG Plasma-Quad PQ1 at the Institute of Geosciences of the University of Kiel and a Finnigan MAT Element 2 double-focusing, single collector ICPMS at the Department of Geosciences of the University of Bremen, Germany (Table 2).

[19] The samples were dissolved by performing a pressurized $\mathrm{HF}-\mathrm{HCl}-\mathrm{HNO}_{3}$-aqua regia attack [Garbe-Schönberg, 1993]. The bulk rock samples were subjected to high-pressure conditions for $48 \mathrm{~h}$ at $200^{\circ} \mathrm{C}$ during this dissolution stage in order to dissolve refractory phases (e.g., spinel) quantitatively. Analyses of duplicates return consistent results with reproducibilities mostly better than $5 \%$. The accuracy of the analyses was monitored using international rock standards $\mathrm{AGV}-1$ (andesite), BHVO-1, BHVO-2 and BIR-1 (basalts), JR-1 (rhyolite) and UB-N (serpentinite) [Govindaraju, 1994; Jochum et al., 2005; S. A. Wilson, Data compilation for USGS reference material BHVO-2, Hawaiian basalt, http://crustal.usgs.gov/geochemical reference_standards/basaltbhvo2.html, 1997]. Our 
Table 3. Isotopic Compositions $\left({ }^{87} \mathrm{Sr} /{ }^{86} \mathrm{Sr}, \delta^{18} \mathrm{O}\right)$ and Formation Temperatures of LHF Samples

\begin{tabular}{|c|c|c|c|c|}
\hline Sample & Sample Type & ${ }^{87} \mathrm{Sr} /{ }^{86} \mathrm{Sr}$ & $\delta^{18} \mathrm{O}(\%)$ & Formation Temperature \\
\hline $33-1$ & gabbronorite & 0.70290 & - & - \\
\hline $74-1 \mathrm{~A}$ & gabbronorite & 0.70291 & - & - \\
\hline $33-12$ & serpentinized peridotite & 0.70874 & - & - \\
\hline $77-1$ & serpentinized peridotite & 0.70907 & - & - \\
\hline $33-11$ & lizardite separate & 0.70951 & 5.4 & $150-172^{\circ} \mathrm{C}^{\mathrm{a}}$ \\
\hline $35-9$ & lizardite separate & 0.70898 & 6.3 & $136-155^{\circ} \mathrm{C}^{\mathrm{a}}$ \\
\hline $62-1 B$ & lizardite separate & 0.70943 & 5.4 & $150-172^{\circ} \mathrm{C}^{\mathrm{a}}$ \\
\hline $74-2 \mathrm{C}$ & lizardite separate & 0.70961 & 6.9 & $128-145^{\circ} \mathrm{C}^{\mathrm{a}}$ \\
\hline $78-2 \mathrm{~B}$ & lizardite separate & 0.70959 & 6.5 & $133-151^{\circ} \mathrm{C}^{\mathrm{a}}$ \\
\hline $35-4 \mathrm{~A}$ & chlorite separate & 0.70833 & 5.6 & $212-237^{\circ} \mathrm{C}^{\mathrm{b}}$ \\
\hline $250-4$ & chlorite separate & 0.70924 & - & - \\
\hline $239-4 \mathrm{~A}$ & talc fragment & 0.70911 & 6.4 & $200-231^{\circ} \mathrm{C}^{\mathrm{b}}$ \\
\hline $239-4 B$ & talc separate & 0.70922 & - & - \\
\hline $250-5$ & quartz fragment & - & 13.1 & $200-227^{\circ} \mathrm{C}^{\mathrm{c}}$ \\
\hline
\end{tabular}

${ }^{\mathrm{a} Z h e n g}$ [1993].

${ }^{\mathrm{b}}$ Savin and Lee [1988].

'Sharp and Kirschner [1994].

values are within $<5 \%$ of the recommended values for UB-N (serpentinite), BHVO-2 and BIR-1 (basalts). Higher deviations in some elements $(\mathrm{Cr}, \mathrm{Rb}, \mathrm{Eu})$ were noted for AVG-1 (andesite; Cr: 16-25\%; Eu: 16\%), BHVO-1 (basalt, Rb: 14-18\%), and JR-1 (rhyolite, Cr: 16-25\%; Rb: $14-18 \%)$. The origin of these deviations is unclear but we consider that they have no significant impact on the interpretation of our results.

\subsection{1. ${ }^{87} \mathrm{Sr} /{ }^{86} \mathrm{Sr}$ Analyses}

[20] The $\mathrm{Sr}$ isotope ratios were measured for 4 bulk rock samples (2 serpentinized peridotite, 2 gabbronorites) and 9 mineral separates (5 lizardite, 2 chlorite, 2 talc) at the Geomar in Kiel (thermal ionization mass spectrometry, ThermoFinnigan TRITON; Table 3). Standard chemical separation (Sr-Spec; 50-100 mesh; $0.6 \mathrm{ml}$ ) and measurement procedures were applied [White and Patchett, 1984]. Blanks were less than $1 \%$ of the total sample amount and therefore negligible. During the course of the analyses seven individual measurements of the NBS 987 standard were obtained yielding an Sr-isotopic ratio of 0.71024 . In addition, six individual measurements of the IAPSO standard seawater yielded a Sr-isotopic ratio of 0.70918 [Palmer and Edmond, 1989].

\subsection{2. $\delta^{18} \mathrm{O}$ Analyses}

[21] Oxygen isotope analyses have been obtained from 4 lizardite separates, 1 chlorite separate, 1 talc sample and a quartz fragment (Table 3). Prior to the isotope analysis, any potentially present $\mathrm{Fe}$ - and Mn-oxides were removed following procedures outlined by Mehra and Jackson [1958]. Oxygen was extracted from the silicates using the $\mathrm{ClF}_{3}$ method. The samples were transferred to nickel reaction vessels and heated under vacuum for $2 \mathrm{~h}$ at $150^{\circ} \mathrm{C}$. All samples were then reacted with $\mathrm{ClF}_{3}$ at $600^{\circ} \mathrm{C}$ for $12 \mathrm{~h}$. Oxygen was quantitatively converted to $\mathrm{CO}_{2}$ which then was analyzed in a Finnigan MAT 251 stable isotope mass spectrometer at the Geomar in Kiel. Oxygen isotope ratios are expressed in the conventional $\partial$-notation as deviation in \%o from VSMOW (Vienna Standard Mean Ocean Water). The analytical error of oxygen isotope analyses was determined to be $\pm 0.2 \%$.

[22] For the calculation of formation temperatures the formulas and fractionation coefficients from Zheng [1993] for lizardite, Savin and Lee [1988] for chlorite and talc, as well as Sharp and Kirschner [1994] for quartz (Table 3) have been used together with $\delta^{18} \mathrm{O}$ values of $1.45 \%$ for the LHF hydrothermal fluid [Schmidt et al., 2011] and 0.3\%o of the pore waters $(\mathrm{H}$. Strauß, personal communication, Münster, Germany, 2010). Therefore we give a range for the formation temperatures calculated by using pore water $\delta^{18} \mathrm{O}$ for the lower end and the $\delta^{18} \mathrm{O}$ values of the hydrothermal fluid for the high temperatures in the formulas mentioned above.

\section{Results}

\subsection{Trace Element and Rare Earth Element Data}

[23] The trace element compositions of serpentinized peridotite are highly variable and primitive mantlenormalized values range over several orders of 
Geochemistry
Geophysics

AUGUSTIN ET AL.: SERPENTINITE ALTERATION AT THE LHF

10.1029/2011GC003903
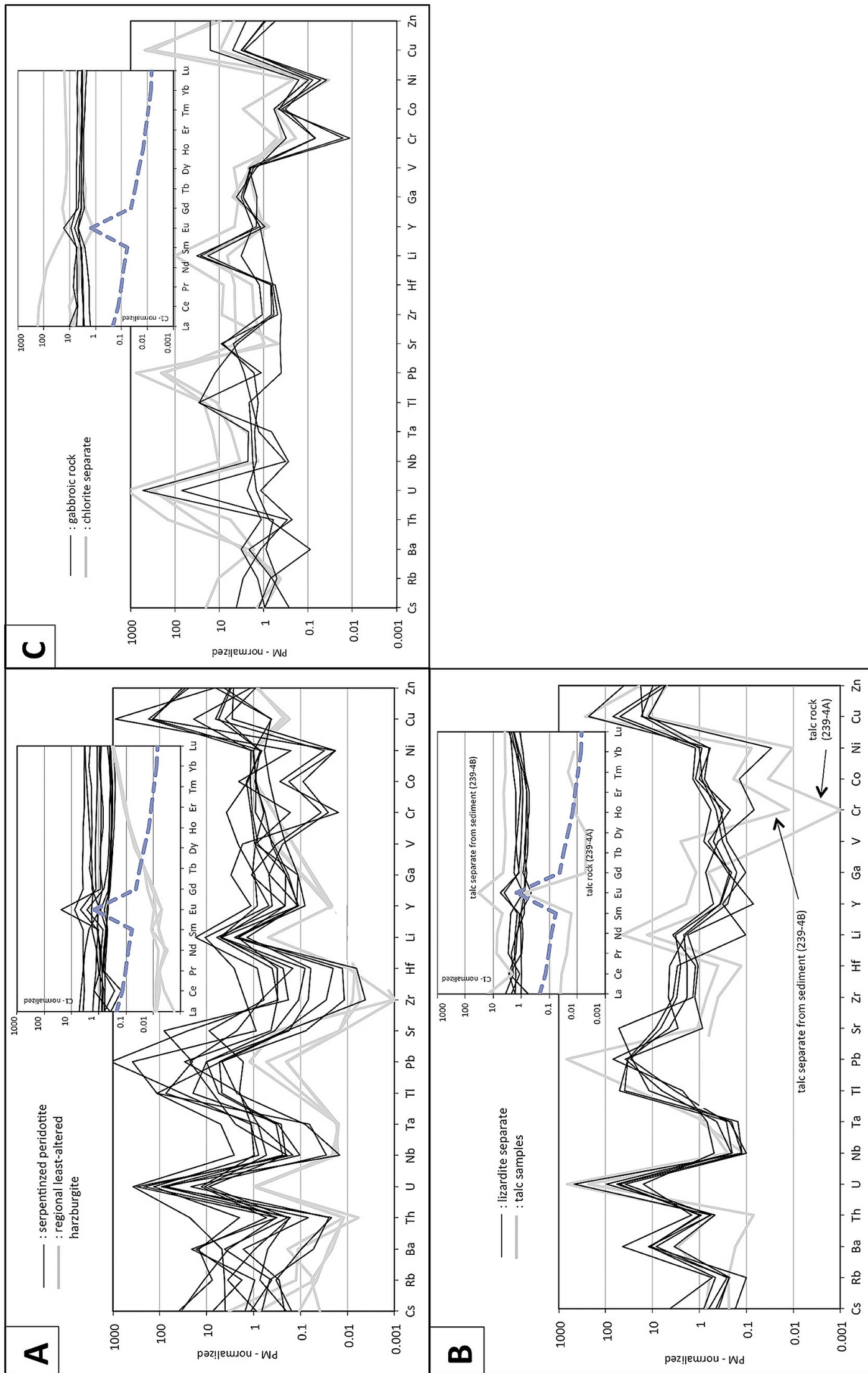

瓷 
magnitude (Figure 2a). Compared to least-altered harzburgite from the $15^{\circ} 20^{\prime} \mathrm{N}$ area obtained by scientific drilling (ODP Leg 209 [Kelemen et al., 2007; Paulick et al., 2006]) the LHF serpentinized peridotites are generally enriched in incompatible elements ( $\mathrm{Cs}$ to $\mathrm{Zr}$ ) and in $\mathrm{Cu}$ and $\mathrm{Zn}$. Their rare earth element (REE) pattern are characterized by flat shapes with commonly developed positive Eu anomalies and some samples showing negative $\mathrm{Ce}$ anomalies. This is in marked contrast to the strongly Light REE depleted pattern of common least-altered harzburgite from depleted mantle sections [e.g., Salters and Stracke, 2004].

[24] The data for lizardite separates follow the same trends as the serpentinized peridotite data with particularly strong enrichments in elements indicating hydrothermal alteration such as $\mathrm{Ba}, \mathrm{U}, \mathrm{Pb}$, $\mathrm{Cu}$, and $\mathrm{Zn}$ (Figure 2b). The REE patterns are also characterized by flat shapes with some samples showing positive $\mathrm{Eu}$ anomalies. The two talc samples analyzed from the remote site 239 are also similar in their trace element characteristics to the LHF serpentinized peridotite. However, they show marked differences in REE pattern. The talc separate from sediment has a pattern similar to the lizardite separates except for a strongly developed negative Ce anomaly (Figure 2b). In contrast, the talc rock sample has very low REE concentrations and its REE pattern overlaps with the pattern for LHF black smoker fluid.

[25] These variations in geochemical compositions indicate that the peridotite host rock to the LHF experienced compositional modifications under diverse conditions. Evidence for melt-rock interaction, hydrothermal alteration and interaction with ambient seawater will be examined in Section 5.

[26] In contrast, the trace element patterns of gabbronorites are less heterogeneous and characterized by elevated $\mathrm{U}, \mathrm{Tl}, \mathrm{Sr}$ and $\mathrm{Li}$ as well as low $\mathrm{Cr}$ and $\mathrm{Ni}$ (Figure 2c). In addition, two samples show elevated $\mathrm{Cu}$ and $\mathrm{Zn}$. All other trace elements indicate only slight enrichment and/or depletion in their concentration compared to primitive mantle. The REE pattern for gabbro samples are flat with minor positive $\mathrm{Eu}$ anomalies. The chlorite separates show similar patterns but have minor negative $\mathrm{Eu}$ anomalies (Figure 2c).

\subsection{Isotopic Composition}

[27] Strontium and oxygen isotopic composition of bulk rock samples and clay mineral separates have been determined (Table 3). The ${ }^{87} \mathrm{Sr} /{ }^{86} \mathrm{Sr}$ ratios $(0.7087$ to 0.7096$)$ of bulk rock serpentinites $(n=4)$ as well as lizardite $(n=5)$ and talc $(n=2)$ separates are close to the seawater value $(0.7092)$. The chlorite separates show similar ${ }^{87} \mathrm{Sr} /{ }^{86} \mathrm{Sr}$ ratios $(0.7083$ and 0.7092), whereas the analyzed gabbronorites $(\mathrm{n}=2)$ yield ${ }^{87} \mathrm{Sr} /{ }^{86} \mathrm{Sr}$ ratios of $\sim 0.7029$.

[28] Fairly homogenous $\delta^{18} \mathrm{O}$ values of around $6.3 \%$ o $( \pm 0.6 \%)$ have been determined for the lizardite separates $(n=5)$. Similarly, the talc sample 239GTV-4A from the remote station 239 has a $\delta^{18} \mathrm{O}$ value of $6.4 \%$, whereas one chlorite separate (35GTV-4A) yields a $\delta^{18} \mathrm{O}$ value of $5.6 \%$. The quartz sample 250GTV-5 from a hydrothermal crust has a $\delta^{18} \mathrm{O}$ value of $13.1 \%$.

[29] The $\delta^{18} \mathrm{O}$ values of the mineral precipitates for the calculation of precipitation temperatures based on formulas and fractionation coefficients from Zheng [1993] for lizardite, Savin and Lee [1988] for chlorite and talc, as well as Sharp and Kirschner [1994] for quartz (Table 3). Therefore Lizardites in the vicinity of the LHF reveal formation temperatures of $128-172^{\circ} \mathrm{C}$, whereas the low temperature end is calculated with the influence of only pore waters and the high temperature has been calculated for a formation under the influence of hydrothermal fluid. One chlorite (35GTV-4A) separate shows higher precipitation temperatures of $212-237^{\circ} \mathrm{C}$. Both, the talc sample $239 \mathrm{GTV}-4 \mathrm{~A}$ and the quartz fragment 250GTV-5 give calculated formation temperatures of 200 to $\approx 230^{\circ} \mathrm{C}$.

\section{Discussion}

\subsection{Geochemical Fingerprints of Melt/ Rock Interaction in the LHF Subsurface}

[30] Geochemical, isotopic and mineralogical traces of melt/rock interaction processes are a common phenomenon in peridotite and have been studied from marine samples and ophiolitic successions [e.g., Godard et al., 1995; Seyler and Bonatti, 1997; Batanova et al., 1998; Piccardo et al., 2003].

Figure 2. Primitive mantle (PM) normalized trace element pattern and C1 normalized REE pattern of LHF samples and mineral separates (normalization data from McDonough and Sun [1995]). Thick dashed line in REE diagrams is LHF black smoker fluid [Schmidt et al., 2007]. (a) Composition of serpentinized peridotite from the LHF (black lines) compared to least-altered harzburgite from the $15^{\circ} 20^{\prime} \mathrm{N}$ area (gray lines, obtained during ODP Leg 209 , data from Paulick et al. [2006]). (b) Composition of lizardite mineral separates (black lines) and talc samples from site 239 (gray lines). (c) Composition of gabbronorites (black lines) and chlorite mineral separates (gray lines). 
Evidence of such processes in the MAR segment adjacent to the $15^{\circ} 20^{\prime}$ Fracture Zone has been presented previously [Godard et al., 2008; Seyler et al., 2007; Suhr et al., 2008; Paulick et al., 2006]. Trace element data from the LHF serpentinized peridotite indicate that the geochemical fingerprints of melt/ rock interaction can be preserved even in intensely altered ultramafic rocks.

[31] A characteristic geochemical feature related to the reaction of percolating melt with surrounding peridotite is the concordant increase of REE and high-field strength element (HFSE; e.g., Zr, Hf, Nb, and $\mathrm{Ta}$ ) concentrations in bulk-rock peridotite samples [e.g., Niu, 2004]. This is due to the fact that REE and HFSE have similar solubility in mafic melts and this signature is transferred to the peridotite. In contrast, under seafloor hydrothermal conditions, HFSE are highly immobile due to low solubilities in aqueous solutions.

[32] The trace element compositions of serpentinized peridotite from the LHF show enrichments in HFSE (Figure 2). Furthermore, Figure 3 shows that there are positive correlations of La with HFSE indicating that REE and HFSE were incorporated into the peridotite by a common process. This indicates that the geochemical composition of the LHF peridotite host rock was already modified prior to fluid/rock interaction due to interaction with percolating melts.

\subsection{High-Temperature Hydrothermal Alteration and Interaction With Ambient Seawater}

[33] The trace element composition of the LHF samples show evidence for both alteration at low temperature conditions and interaction with hightemperature black smoker type fluids. The most prominent indication for high-temperature fluid/ rock interaction can be deduced from the $\mathrm{Cu}$ and Zn data.

[34] The vent fluids at the LHF are highly enriched in the trace metals $\mathrm{Cu}(2800 \mathrm{ppb})$ and $\mathrm{Zn}(2350 \mathrm{ppb})$ compared to seawater $(0.2 \mathrm{ppb}$ and $18.3 \mathrm{ppb}$, respectively [Schmidt et al., 2007]). This type of enrichment is a common characteristic for black smoker type hydrothermal fluids and is generally attributed to base metal leaching at depth [e.g., Seewald and Seyfried, 1990].

[35] Most of the LHF serpentinites also show highly elevated $\mathrm{Cu}$ and $\mathrm{Zn}$ concentrations (up to $\sim 2.7 \mathrm{wt} \%$ and $\sim 0.2 \mathrm{wt} \%$ respectively) compared to least altered mantle peridotite (Table 2 and Figure 2).

[36] Several features in the trace element data indicate serpentinite interaction with ambient seawater under low-T conditions. Fresh peridotites have low Sr contents and can easily be influenced by seawater $\mathrm{Sr}$, so the locally high values of $\mathrm{Sr}$ and, to a minor extent, $\mathrm{Rb}$ (Figure 2) are best interpreted as the result of low-temperature seawater alteration since Hart et al. [1974] showed that $\mathrm{Rb}$ and $\mathrm{Sr}$ are readily supplied by seawater and easily incorporated into, or absorbed on, secondary clay minerals or carbonates. This could also be the most likely interpretation of the elevated $\mathrm{Ba}$ contents in the serpentinites and lizardites even though LHF black smoker fluids are somewhat enriched in $\mathrm{Ba}$ [Douville et al., 2002]. Similarly, low temperature alteration is also reflected by the addition of $U$ and $\mathrm{Pb}$ to the LHF samples. Such increased $\mathrm{U}$ and $\mathrm{Pb}$ concentrations are known from oxidatively altered rocks of the ocean crust penetrated by ODP drill hole 504B [Bach et al., 2003] and seawater-altered basalts [Verma, 1992].

\subsection{Hydrothermal Controls on Rare Earth Element Variations}

[37] It has been shown by previous studies that LREE and Eu may be added during the serpentinization of peridotites when fluid/rock ratios are high and hot, black smoker type fluids are involved ("fluid-dominated serpentinization" of Paulick et al. [2006]). This is in accordance with findings of previous investigations regarding REE mobility [Ludden and Thompson, 1979; Humphris and Thompson, 1983; Poitrasson et al., 1995; Négrel et al., 2000]. The mobility of LREE and the development of Eu-anomalies may provide evidence regarding the proportions of the fluid end-members during hydrothermal alteration [Allen and Seyfried, 2005; Bau, 1991; Delacour et al., 2008]

[38] The LHF serpentinite samples and lizardite separates have flat to slightly U-shaped REE patterns and commonly show positive Eu anomalies. The hydrothermal vent fluids discharging at the LHF show strongly increased LREE $\left(\mathrm{La}_{N} / \mathrm{Lu}_{\mathrm{N}} \sim\right.$ 39.0) with a strong positive $\mathrm{Eu}$ anomaly $\left(\mathrm{Eu}_{\mathrm{N}} /\right.$ $\mathrm{Eu}^{*}{ }_{\mathrm{N}} \sim 35.0$, Figure 4 [Schmidt et al., 2007]). Bau [1991] explained positive $\mathrm{Eu}$ anomalies in hot alteration fluids by the presence of $\mathrm{Eu}^{2+}$ at mildly acidic conditions where LREE are also enriched in the fluid $\left(\mathrm{La}_{N} / \mathrm{Lu}_{\mathrm{N}}>1\right)$. In contrast, no positive $\mathrm{Eu}$ anomalies and associated $\mathrm{La}_{N} / \mathrm{Lu}_{\mathrm{N}}<1$ are indicators 

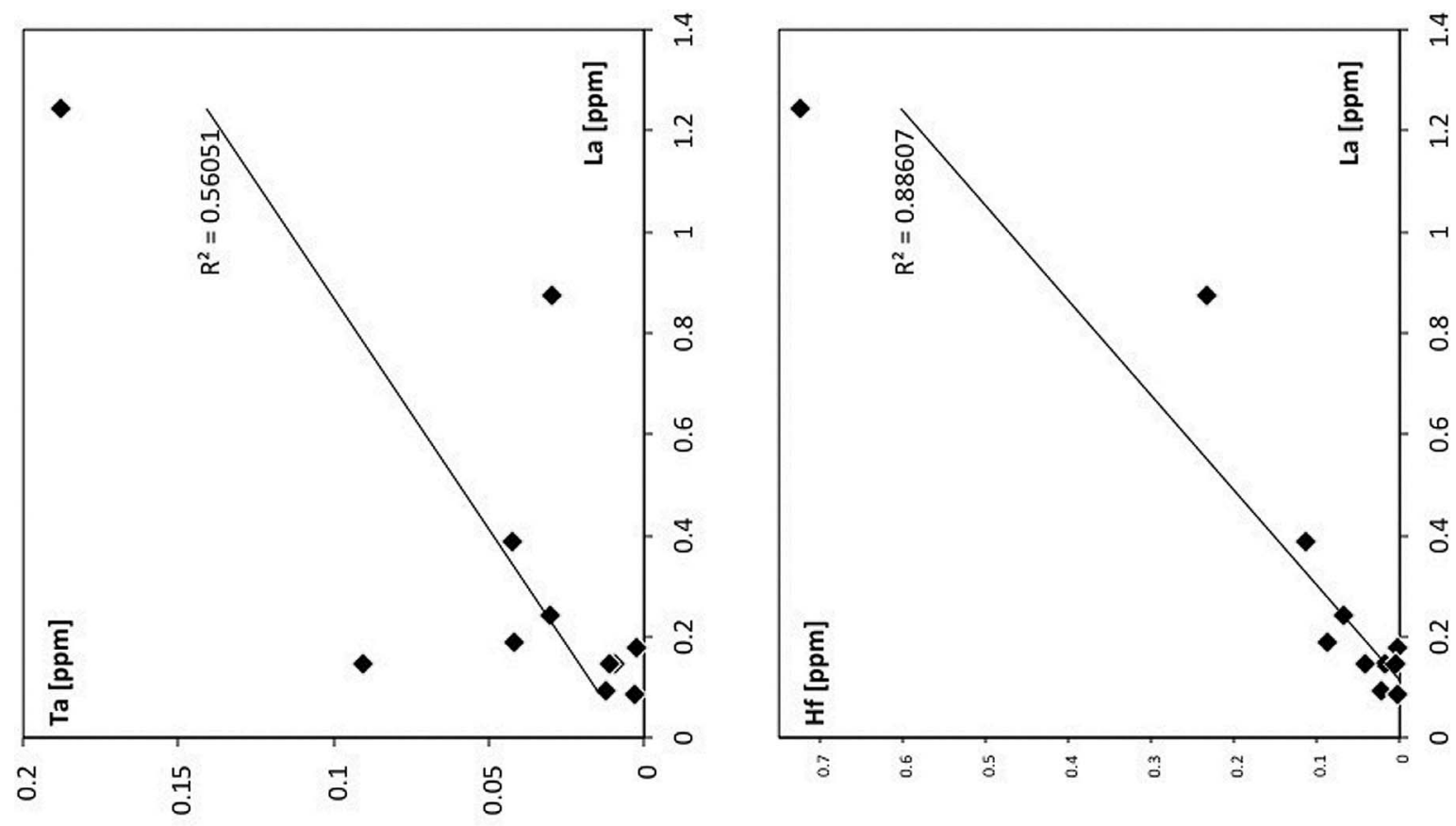

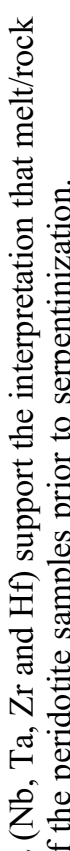
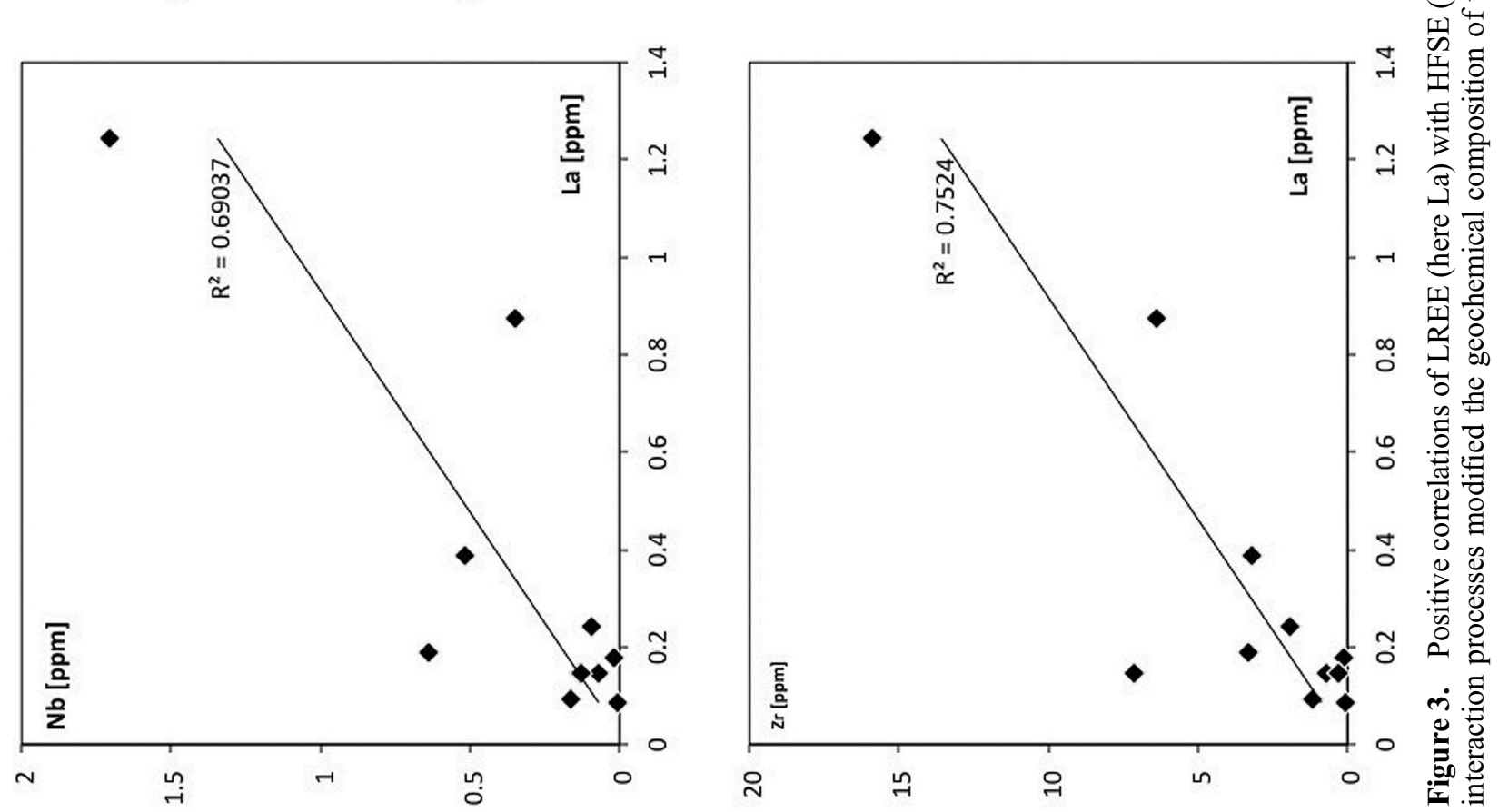


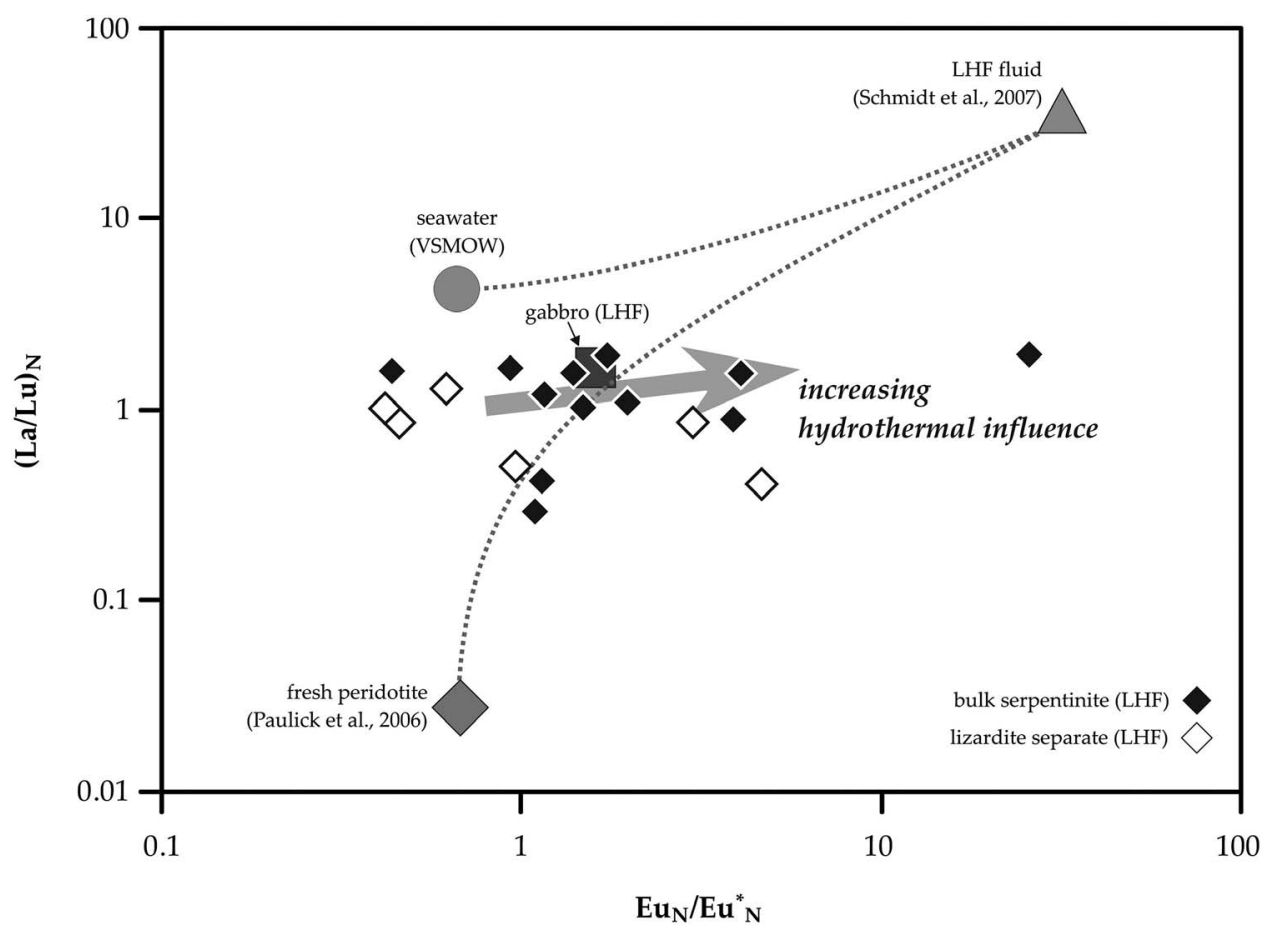

Figure 4. The LHF serpentinites and lizardite separates show strong variations in the REE pattern. In this figure, the variations in relative proportions of LREE to $\operatorname{HREE}\left(\mathrm{La}_{\mathrm{N}} / \mathrm{Lu}_{\mathrm{N}}\right)$ and the development of Eu anomalies $\left(\mathrm{Eu}_{\mathrm{N}} / \mathrm{Eu}^{*}{ }_{\mathrm{N}}\right)$ are compared to the composition of LHF black smoker fluid, seawater and regional fresh peridotite. An increasing hydrothermal influence is inferred for samples with increasing positive Eu anomalies (dashed lines represent assumed linear mixing lines between seawater, the host rocks and the hydrothermal fluid).

for fluid rock interaction under neutral to mildly basic conditions in more reducing environments [Ludden and Thompson, 1979; Bau, 1991].

[39] Figure 4 illustrates the variation of $\mathrm{La}_{N} / \mathrm{Lu}_{N}$ in relation to $\mathrm{Eu}_{\mathrm{N}} / \mathrm{Eu}^{*}{ }_{\mathrm{N}}$ of serpentinite samples and lizardite separates. The $\mathrm{La}_{\mathrm{N}} / \mathrm{Lu}_{\mathrm{N}}$ values (range 0.2-5.9, average 1.4) show no correlation with $\mathrm{Eu}_{\mathrm{N}} / \mathrm{Eu}^{*}$. This suggests a decoupling of these two parameters and, likely, the $\mathrm{La}_{\mathrm{N}} / \mathrm{Lu}_{\mathrm{N}}$ values are predominantly controlled by melt-rock interaction processes as discussed above.

[40] However, the range of $\mathrm{Eu}_{\mathrm{N}} / \mathrm{Eu}^{*}{ }_{\mathrm{N}}$ ratios observed for the samples is large and includes values similar to seawater and values similar to the hydrothermal LHF fluid (Figure 4). We infer that samples showing strong positive Eu anomalies were affected most by high temperature hydrothermal alteration. The sample with the highest $\mathrm{Eu}_{\mathrm{N}} / \mathrm{Eu}^{*}{ }_{\mathrm{N}}$ value $(25.8$, sample $35-1 \mathrm{~F})$, was obtained from the immediate vicinity of the black smoker complex IRINA II. This is consistent with our interpretation of a strong hydrothermal overprint.

[41] The large range of the $\mathrm{Eu}$ anomalies probably reflects the varying physico-chemical conditions in the Logatchev hydrothermal system which include fluid-cooling processes and mixing with seawater in various proportions in the shallow sub-seafloor environment beneath hydrothermal crusts or in sediment covered aquifers. End-member samples with $\mathrm{Eu}_{\mathrm{N}} / \mathrm{Eu}^{*}{ }_{\mathrm{N}}$ values $<1$ are interpreted to reflect alteration conditions dominated by ambient seawater-like fluids.

\subsection{Talc Alteration}

[42] Talc samples have been obtained from the TV-grab station 239 at a distance of ca. $300 \mathrm{~m}$ from the LHF. Monomineralic talc rocks in ocean floor settings are uncommon but have been previously reported [e.g., Bach et al., 2004; D'Orazio et al., 2004; Boschi et al., 2006]. Since talc has no preferences for $\mathrm{Eu}^{2+}$ nor discriminates against $\mathrm{Ce}^{4+}\left[D^{\prime}\right.$ Orazio et al., 2004] it can be inferred that the presence of Eu and $\mathrm{Ce}$ anomalies in the REE pattern of the two analyzed talc samples are probably inherited from the precursor mineral phases or the fluid phase involved in talc formation.

[43] The two talc samples from TV-grab station 239 have significantly different REE patterns: 


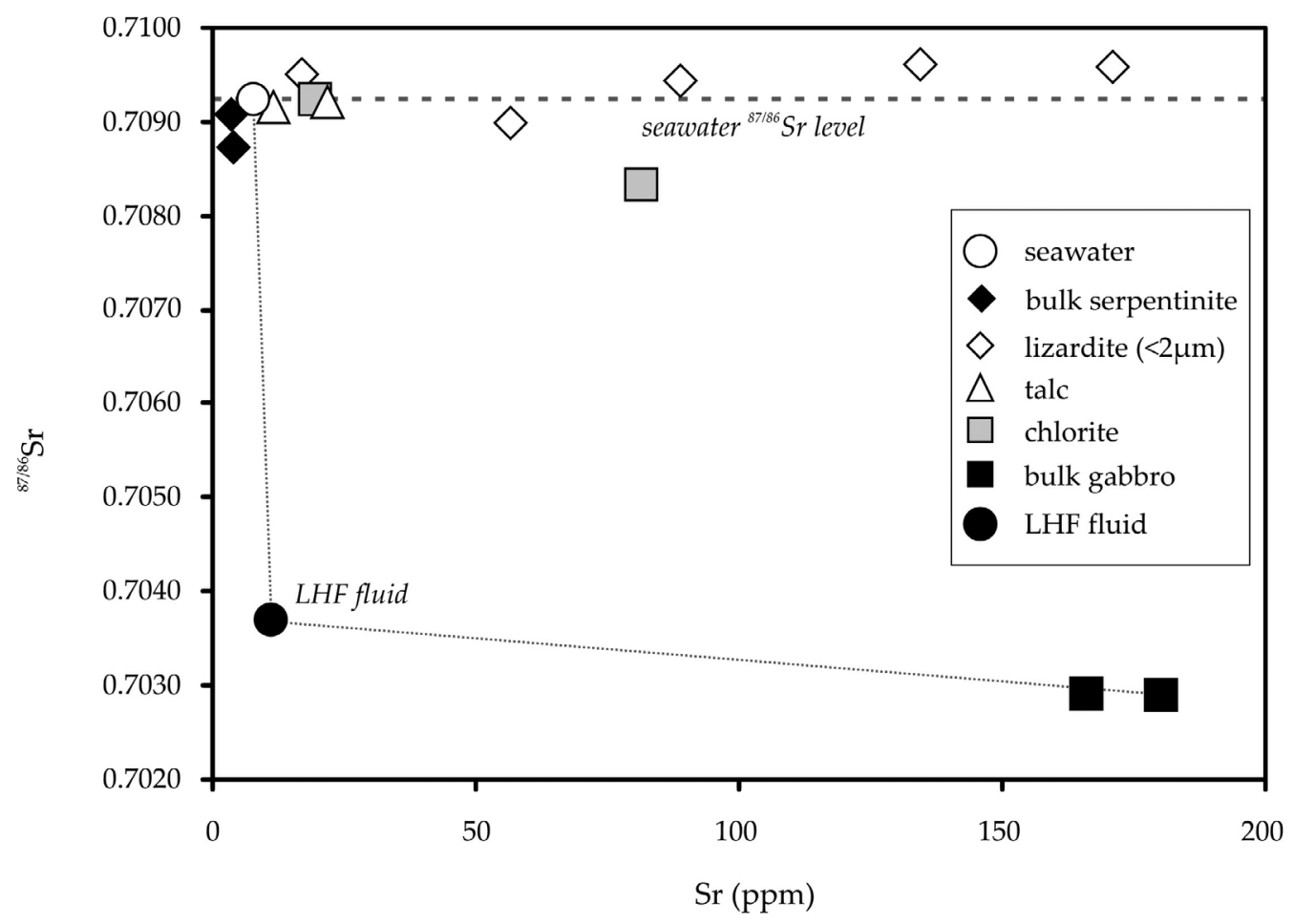

Figure 5. The ${ }^{87} \mathrm{Sr} /{ }^{86} \mathrm{Sr}$ ratios of serpentinite and mineral separates (lizardite, chlorite, and talc) are similar to the value for seawater. The LHF black smoker fluids are considerably less radiogenic [Amini, 2007] which indicates that they interacted with gabbroic rocks in the subsurface.

[44] 1. The talc rock (sample 239-4A) has low REE concentrations and a REE pattern very similar to that of the Logatchev hydrothermal fluid, indicating a strong influence of hot vent fluids. A formation temperature of $\sim 230^{\circ} \mathrm{C}$ is indicated by the oxygen isotope data (Table 3).

[45] 2. The second talc sample (239-4B; separate from talc-rich mud) shows a flat, REE enriched pattern with a pronounced negative Ce-anomaly. This is comparable to some bulk rock serpentinite samples. Potentially, this talc sample may originate from Si-metasomatism of serpentinite with limited modification to REE systematics.

[46] Alt et al. [2007] used S isotopes (combined with $\mathrm{O}$ isotopes) to indicate the same process for Leg 209 talc-serpentine. Based on a Cl-O-H isotope investigation, Barnes et al. [2009] inferred that talc alteration support the interpretation of serpentinite was associated with the emplacement of gabbro into serpentinized peridotite lithosphere. A similar scenario at Logatchev would be consistent with the comparatively $\mathrm{SiO}_{2}$ rich composition of Logatchev hydrothermal vent fluids which suggest fluid/gabbro interaction at depth [Douville et al., 2002; Schmidt et al., 2007]. We infer that talc alteration of serpentinite at site 239 was due to interaction with Si-rich fluids, which previously interacted with gabbroic rocks. The talc separate from sediment has a negative $\mathrm{Ce}$ anomaly and elevated $\mathrm{Li}$ and $\mathrm{Pb}$ contents, which indicate that substantial interaction with low- $T$ ambient seawater, modified the trace element composition of this sample.

\section{5. ${ }^{87 / 86} \mathrm{Sr}$ Ratios}

[47] The strontium isotope data provide important constraints on fluid rock interaction processes and fluid composition [Bickle and Teagle, 1992; Kimball and Gerlach, 1986; Lackschewitz et al., 2004; Teagle et al., 1998]. Figure 5 illustrates the ${ }^{87} \mathrm{Sr} /{ }^{86} \mathrm{Sr}$ ratios of the LHF samples and mineral separates. The ${ }^{87} \mathrm{Sr} /{ }^{86} \mathrm{Sr}$ ratios of serpentine, chlorite and talc are close to the seawater value for north Atlantic seawater $\left({ }^{87} \mathrm{Sr} /{ }^{86} \mathrm{Sr}=0.70918\right.$ [Palmer and Edmond, 1989]). In contrast, 4 out of 5 lizardite samples show somewhat higher ${ }^{87} \mathrm{Sr} /{ }^{86} \mathrm{Sr}$ ratios (up to 0.7096). This feature is difficult to explain since the $\mathrm{Sr}$ isotope composition of seawater shows no significant variability in recent deep seawaters [Faure et al., 1965; Hamilton, 1966; Palmer and Edmond, 1989; Rama Murthy and Beiser, 1968; Frank, 2002] and an increase of the radiogenic ${ }^{87} \mathrm{Sr}$ by 
in situ ${ }^{87} \mathrm{Rb}-{ }^{87} \mathrm{Sr}$ decay is unlikely to be significant, since the LHF is situated on $\sim 300 \mathrm{ka}$ old oceanic crust (distance from spreading axis: $\sim 8 \mathrm{~km}$; local spreading rate: $27 \mathrm{mma}^{-1}$ ) and $\mathrm{Rb}$ concentrations are very low (Tab. 3; $\mathrm{Rb} / \mathrm{Sr}<0.01$ for lizardites samples). Potentially, these elevated ${ }^{87} \mathrm{Sr} /{ }^{86} \mathrm{Sr}$ ratios could be related to some sort of localized influence by overlaying sediments. Pelagic sediments may be in isotopic disequilibrium with seawater and can show ${ }^{87} \mathrm{Sr} /{ }^{86} \mathrm{Sr}$ ratios of up to 0.739 [Dasch et al., 1966; Rama Murthy and Beiser, 1968]. In addition a presence of small amounts of continental crust-derived clay could rise ${ }^{87} \mathrm{Sr} /{ }^{86} \mathrm{Sr}$ ratios [Snow et al., 1993]. In this scenario, the variation in ${ }^{87} \mathrm{Sr} /{ }^{86} \mathrm{Sr}$ values of the lizardite separates could be an indication of small-scale exchange processes under low-T conditions. This is consistent with their strongly elevated $\mathrm{Sr}$ concentrations, which are interpreted as fingerprints of alteration processes dominated by ambient seawater.

[48] Interestingly, bulk rock serpentinite samples (33-12 and 77-1A; Table 1) have lower ${ }^{87} \mathrm{Sr} /{ }^{86} \mathrm{Sr}$ ratios than the lizardite. This could be due to the presence of relic clinopyroxene or plagioclase with less radiogenic ${ }^{87} \mathrm{Sr} /{ }^{86} \mathrm{Sr}$ ratios than the volumetrically predominant lizardite. However, ${ }^{87} \mathrm{Sr} /{ }^{86} \mathrm{Sr}$ fractionation due to clay-sized crystal grain sizes may also play a role which has been previously observed for $\mathrm{Sr}$ isotopes [Eisenhauer et al., 1999], where different grain sizes display differences in measured isotope ratios. This differences can be explained by crystal growth mechanisms and surface energy effects of nanoscale crystals [Williams and Hervig, 2005]. However, the serpentines grew at high temperatures $\left(130-170^{\circ} \mathrm{C}\right)$ from a fluid that very likely had ${ }^{87} \mathrm{Sr}{ }^{86} \mathrm{Sr}$ ratios much lower than modern seawater, which suggests that growth mechanisms seem to be unlikely. In addition, Watson [2004] demonstrated that crystal surfaces may have different isotopic signatures than the bulk crystal, which point to surface energy effects of nanoscale crystals as described by Williams and Hervig [2005]. Hence, a combination of different factors are probably influence the elevated ${ }^{87} \mathrm{Sr} /{ }^{86} \mathrm{Sr}$ signature of the lizardite separates compared to bulk rock serpentinite samples and seawater.

[49] Least altered gabbronorites (LOI < 1.6) reveal substantially lower ${ }^{87} \mathrm{Sr} /{ }^{86} \mathrm{Sr}$ ratios $(0.70290$ to $0.70291)$ than the bulk rock serpentinite samples (0.70874 to 0.70907$)$. The values of the gabbronorites are close to the ${ }^{87} \mathrm{Sr} /{ }^{86} \mathrm{Sr}$ ratio of the endmember hydrothermal fluid at Logatchev (0.7037 [Amini et al., 2008]), which is consistent with the interpretation that these fluids interacted with gabbronorite prior to and/or during ascent in the Logatchev hydrothermal system.

[50] In general, Sr-isotopic data may also be regarded as a tracer for the evolution of circulating fluids (starting composition in the recharge zone: ${ }^{87} \mathrm{Sr} /{ }^{86} \mathrm{Sr} 0.7092$ ) during their passage through and reaction with the oceanic crustal rocks $\left({ }^{87} \mathrm{Sr} /{ }^{86} \mathrm{Sr}\right.$ of mafic rocks are $\leq 0.703$ ). Thus, $\mathrm{Sr}$ isotope characteristics of the evolved hydrothermal fluid, discharging at the seafloor can provide a measure of the degree of interaction of seawater with the crust [Alt et al., 1996; Delacour et al., 2008]. The Sr isotope composition of Logatchev end-member fluid (0.7037 [Amini et al., 2008]) is somewhat higher than the ${ }^{87} \mathrm{Sr} /{ }^{86} \mathrm{Sr}$ of gabbronorites $(0.70290$ and 0.70291). This maybe interpreted as an indication that interaction with serpentinized peridotites also played a role in the evolution of fluid composition. This is consistent with the volumetrically predominance of serpentinite in the sample suite from the LHF.

\section{Conclusions}

[51] Trace element and Sr-O isotope data indicate that the host rocks of the Logatchev hydrothermal system experienced a variety of processes leading to compositional modifications ranging from meltrock interaction to variable styles of hydrothermal alteration. These processes are conceptually illustrated in Figure 6 and can be summarized as follows:

[52] 1. Mafic magma played an important role in the evolution of the LHF host rock succession. It is inferred that mafic melts migrated through the ultramafic mantle rocks leaving geochemical fingerprints in their trace element composition. Localized occurrences of talc alteration show that Si metasomatism overprints serpentinization and reflects the evolution of the hydrothermal system as well as the influence of gabbro intrusion at depth.

[53] 2. Isotopic and geochemical evidences indicate that hydrothermal alteration at Logatchev took place under variable water/rock ratios, fluid mixing, and temperature.

[54] 3. Interaction of peridotite with hot, black smoker-type fluids is indicated by substantial positive $\mathrm{Eu}$ anomalies, strongly elevated $\mathrm{Cu}$ and $\mathrm{Zn}$ concentrations and positive correlations of lizardite formation temperature and $\mathrm{Cu}$ content.

[55] 4. Mixing of hydrothermal fluids and ambient seawater is taking place in secondary hydrothermal 


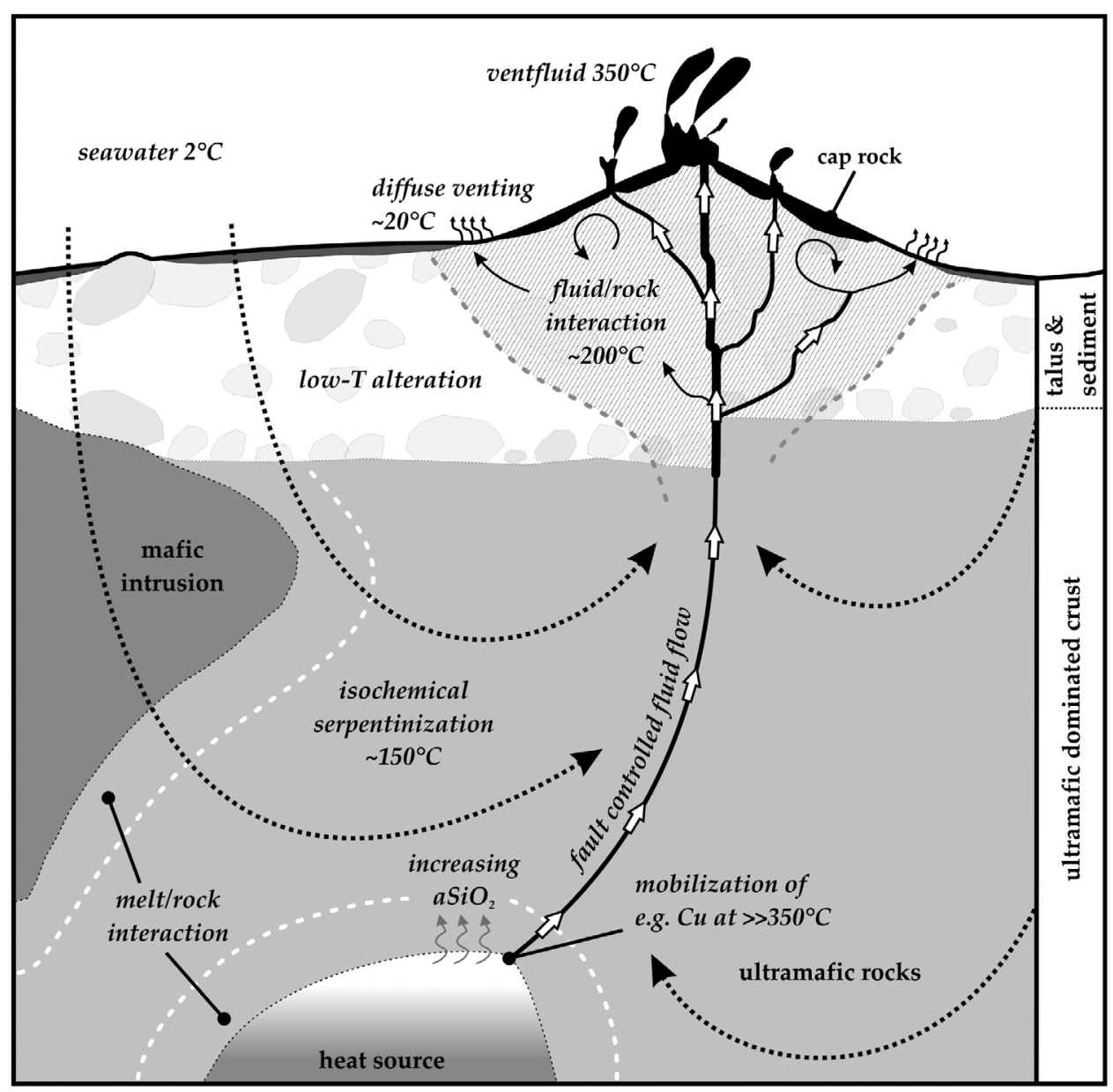

Figure 6. Conceptual sketch of the subsurface processes at the Logatchev hydrothermal field illustrating the relationship of processes discussed in this study. Not to scale.

circulation cells in the near seafloor environment. This is evident from the observation of temperatures of up to $105^{\circ} \mathrm{C}$ in samples recovered from below hydrothermal caprocks in the LHF. In addition, the enrichment of serpentinite and lizardite separates in trace elements such as $\mathrm{Sr}, \mathrm{Rb}, \mathrm{Ba}, \mathrm{U}$, and $\mathrm{Pb}$ indicate a considerable degree of interaction with ambient seawater. Consistently, $\delta^{18} \mathrm{O}$ formation temperatures of mineral separates $\left(128-237^{\circ} \mathrm{C}\right)$ are considerably lower than black smoker fluid exit temperatures (around $350^{\circ} \mathrm{C}$ ), which supports the model of extensive fluid mixing and/or re-equilibration of LHF host rocks with ambient seawater.

\section{Acknowledgments}

[56] Our work was supported by grants from the German Science Foundation (DFG). This is publication 65 of the Special Priority Program SPP 1144 "From Mantle to Ocean: Energy-, Material- and Life cycles at Spreading Axes." We thank all members of the shipboard parties during the cruises
M60/3 and M64/2 as well as the R/V Meteor captain M. Kull and crew. The authors gratefully acknowledge Petra Fiedler (Kiel University) and Jutta Heinze (Geomar) for technical assistance with XRD analyses; Inge Dold (Kiel University) for sample preparation for oxygen isotope analyses; Heike Anders (Bremen University) and Ulrike Westernströer, Heidi Blaschek (Kiel University) for ICP-MS analyses; Ana Kolevica (Geomar) for strontium isotope analyses; Edgars Rudzitis (Geomar) for help with sample preparation; Frieder Klein (Bremen University) and Sven Petersen (Geomar) for helpful discussions. We also thank Jeffrey Alt and Wolfgang Bach for their reviews and comments, which helped us to increase the quality of the paper.

\section{References}

Allen, D. E., and W. E. Seyfried (2005), REE controls in ultramafic hosted MOR hydrothermal system: An experimental study at elevated temperature and pressure, Geochim. Cosmochim. Acta, 69, 675-683, doi:10.1016/j.gca.2004.07.016.

Alt, J. C. (1995), Subseafloor processes in mid-ocean ridge hydrothennal systems, in Seafloor Hydrothermal Systems: Physical, Chemical, Biological, and Geological Interactions, 
Geophys. Monogr. Ser., vol. 91, edited by S. E. Humphris et al., pp. 85-114, AGU, Washington, D. C., doi:10.1029/ GM091p0085.

Alt, J. C., D. A. H. Teagle, W. Bach, A. N. Halliday, and J. Erzinger (1996), Stable and strontium isotopic profiles through hydrothermally altered upper oceanic crust, Hole 504B, Proc. Ocean Drill. Program Sci. Results, 148, 57-69.

Alt, J. C., W. C. Shanks III, W. Bach, H. Paulick, C. J. Garrido, and G. Beaudoin (2007), Hydrothermal alteration and microbial sulfate reduction in peridotite and gabbro exposed by detachment faulting at the Mid-Atlantic Ridge, $15^{\circ} 20^{\prime} \mathrm{N}$ (ODP Leg 209): A sulfur and oxygen isotope study, Geochem. Geophys. Geosyst., 8, Q08002, doi:10.1029/ 2007GC001617.

Amini, M. (2007), The role of high- and low-temperature oceanic crust alteration for the marine calcium budget, doctoral thesis, Christian-Albrechts-Universität zu Kiel, Kiel, Germany. Amini, M., A. Eisenhauer, F. Böhm, J. Fietzke, W. Bach, D. Garbe-Schönberg, M. Rosner, B. Bock, K. S. Lackschewitz, and F. Hauff (2008), Calcium isotope $\left(\delta^{44 / 40} \mathrm{Ca}\right)$ fractionation along hydrothermal pathways, Logatchev field (MidAtlantic Ridge, $\left.14^{\circ} 45^{\prime} \mathrm{N}\right)$, Geochim. Cosmochim. Acta, 72(16), 4107-4122, doi:10.1016/j.gca.2008.05.055.

Augustin, N., K. S. Lackschewitz, and T. Kuhn (2008), Mineralogical and chemical mass changes in mafic and ultramafic rocks from the Logatchev hydrothermal field (MAR $15^{\circ} \mathrm{N}$ ), Mar. Geol., 256, 18-29, doi:10.1016/j.margeo.2008.09.004.

Bach, W., B. Peucker-Ehrenbrink, S. R. Hart, and J. S. Blusztajn (2003), Geochemistry of hydrothermally altered oceanic crust: DSDP/ODP Hole 504B-Implications for seawatercrust exchange budgets and $\mathrm{Sr}$ - and $\mathrm{Pb}$-isotopic evolution of the mantle, Geochem. Geophys. Geosyst., 4(3), 8904, doi:10.1029/2002GC000419.

Bach, W., C. J. Garrido, H. Paulick, J. Harvey, and M. Rosner (2004), Seawater-peridotite interactions: First insights from ODP Leg 209, MAR 15, Geochem. Geophys. Geosyst., 5, Q09F26, doi:10.1029/2004GC000744.

Bach, W., H. Paulick, C. J. Garrido, B. Ildefonse, W. P. Meurer, and S. E. Humphris (2006), Unraveling the sequence of serpentinization reactions: Petrography, mineral chemistry, and petrophysics of serpentinites from MAR $15^{\circ} \mathrm{N}$ (ODP Leg 209, Site 1274), Geophys. Res. Lett., 33, L13306, doi:10.1029/2006GL025681.

Barnes, J. D., H. Paulick, Z. D. Sharp, W. Bach, and G. Beaudoin (2009), Stable isotope $\left(\delta^{18} \mathrm{O}, \delta \mathrm{D}, \delta^{37} \mathrm{Cl}\right)$ evidence for multiple fluid histories in mid-Atlantic abyssal peridotites (ODP Leg 209), Lithos, 110, 83-94, doi:10.1016/j.lithos.2008.12.004.

Batanova, V. G., G. Suhr, and A. V. Sobolev (1998), Origin of geochemical heterogeneity in the mantle peridotites from the Bay of Islands ophiolite, Newfoundland, Canada: Ion probe study of clinopyroxenes, Geochim. Cosmochim. Acta, 62, 853-866, doi:10.1016/S0016-7037(97)00384-0.

Batuyev, B. N., A. G. Kratov, V. F. Markov, G. A. Cherkashev, S. G. Krasnov, and Y. D. Lisitsyn (1994), Massive sulphide deposits discovered at $14^{\circ} 45^{\prime} \mathrm{N}$ Mid-Atlantic Ridge, Bridge Newsl., 6, 6-10.

Bau, M. (1991), Rare-earth element mobility during hydrothermal and metamorphic fluid-rock interaction and the significance of the oxidation stage of europium, Chem. Geol., 93, 219-230, doi:10.1016/0009-2541(91)90115-8.

Bickle, M. J., and D. A. H. Teagle (1992), Strontium alteration in the Troodos ophiolite: Implications for fluid fluxes and geochemical transport in mid-ocean ridge hydrothermal systems, Earth Planet. Sci. Lett., 113, 219-237, doi:10.1016/ 0012-821X(92)90221-G.
Bogdanov, Y. A., E. G. Gurvich, O. Y. Bogdanova, I. V. Vikent'ev, A. V. Sivtsov, A. B. Isaeva, A. I. Gorshkov, and A. M. Sagalevich (2004), Low-temperature deposits of the Logatchev hydrothermal field (Mid-Atlantic Ridge), Geology Ore Deposits, 46, 269-285.

Boschi, C., G. L. Früh-Green, A. Delacour, J. A. Karson, and D. S. Kelley (2006), Mass transfer and fluid flow during detachment faulting and development of an oceanic core complex, Atlantis Massif (MAR $\left.30^{\circ} \mathrm{N}\right)$, Geochem. Geophys. Geosyst., 7, Q01004, doi:10.1029/2005GC001074.

Cannat, M., D. Bideau, and H. Bougault (1992), Serpentinized peridotites and gabbros in the Mid-Atlantic Ridge axial valley at $15^{\circ} 37^{\prime} \mathrm{N}$ and $16^{\circ} 52^{\prime} \mathrm{N}$, Earth Planet. Sci. Lett., 109 , 87-106, doi:10.1016/0012-821X(92)90076-8.

Cannat, M., Y. Lagabrielle, H. Bougault, J. Casey, N. de Coutures, L. Dmitriev, and Y. Fouquet (1997), Ultramafic and gabbroic exposures at the Mid-Atlantic Ridge: Geological mapping in the $15^{\circ} \mathrm{N}$ region, Tectonophysics, 279, 193-213, doi:10.1016/S0040-1951(97)00113-3.

Cherkashev, G. A., A. M. Ashadze, and A. V. Gebruk (2000), New fields with manifestations of hydrothermal activity in the Logatchev area $\left(14^{\circ} \mathrm{N}\right.$, Mid-Atlantic Ridge), InterRidge News, 9, 26-27.

Dasch, E. J., F. A. Hills, and K. K. Turekian (1966), Strontium isotopes in deep-sea sediments, Science, 153, 295-297, doi:10.1126/science.153.3733.295.

Delacour, A., G. L. Früh-Green, M. Frank, M. Gutjahr, and D. S. Kelley (2008), Sr- and Nd-isotope geochemistry of the Atlantis Massif $\left(30^{\circ} \mathrm{N}, \mathrm{MAR}\right)$ : Implications for fluid fluxes and lithospheric heterogeneity, Chem. Geol., 254(1-2), 19-35, doi:10.1016/j.chemgeo.2008.05.018.

Dick, H. J. B. (1989), Abyssal peridotites, very slow spreading ridges and ocean ridge magmatism, in Magmatism in the Ocean Basins, edited by A. D. Saunders and M. J. Norry, Geol. Soc. Spec. Publ., 42, 71-105, doi:10.1144/GSL. SP.1989.042.01.06.

Dick, H. J. B., J. Lin, and H. Schouten (2003), An ultraslowspreading class of ocean ridge, Nature, 426, 405-412, doi:10.1038/nature02128.

Dick, H. J. B., M. A. Tivey, and B. E. Tucholke (2008), Plutonic foundation of a slow-spreading ridge segment: Oceanic core complex at Kane Megamullion, $23^{\circ} 30^{\prime} \mathrm{N}$, $45^{\circ} 20^{\prime} \mathrm{W}$, Geochem. Geophys. Geosyst., 9, Q05014, doi:10.1029/2007GC001645.

Dilek, Y., E. M. Moores, D. Elthon, and A. Nicolas (Eds.) (2000), Ophiolites and Oceanic Crust: New Insight Form Field Studies and Ocean Drilling Program, Spec. Pap. Geol. Soc. Am., vol. 349, 468 pp.

D’Orazio, M., C. Boschi, and D. Brunelli (2004), Talc-rich hydrothermal rocks from the St. Paul and Conrad fracture zones in the Atlantic Ocean, Eur. J. Mineral., 16, 73-83, doi:10.1127/0935-1221/2004/0016-0073.

Douville, E., J. L. Charlou, E. H. Oelkers, P. Bienvenu, C. F. Jove Colon, J. P. Donval, Y. Fouquet, D. Prieur, and P. Appriou (2002), The rainbow vent fluids $\left(36^{\circ} 14^{\prime} \mathrm{N}, \mathrm{MAR}\right)$ : The influence of ultramafic rocks and phase separation on trace metal content in Mid-Atlantic Ridge hydrothermal fluids, Chem. Geol., 184, 37-48, doi:10.1016/S00092541(01)00351-5.

Edmond, J. M., C. Measures, B. Mangum, B. Grant, F. R. Sclater, R. Collier, A. Hudson, L. I. Gordon, and J. B. Corliss (1979a), On the formation of metal-rich deposits at ridge crests, Earth Planet. Sci. Lett., 46, 19-30, doi:10.1016/0012-821X(79) 90062-1. 
Edmond, J. M., C. Measures, R. E. McDuff, L. H. Chan, R. Collier, B. Grant, L. I. Gordon, and J. B. Corliss (1979b), Ridge crest hydrothermal activity and the balances of the major and minor elements in the ocean: The Galapagos data, Earth Planet. Sci. Lett., 46, 1-18, doi:10.1016/0012821X(79)90061-X.

Eisenhauer, A., H. Meyer, V. Rachold, T. Tütken, B. Wiegand, B. T. Hansen, R. F. Spielhagen, F. Lindemann, and H. Kassens (1999), Grain size separation and sediment mixing in Arctic Ocean sediments: Evidence from the strontium isotope systematic, Chem. Geol., 158, 173-188, doi:10.1016/S0009-2541(99)00026-1.

Escartín, J., and M. Cannat (1999), Ultramafic exposures and the gravity signature of the lithosphere near the FifteenTwenty Fracture Zone (Mid-Atlantic Ridge, $14^{\circ}-16,5^{\circ} \mathrm{N}$ ), Earth Planet. Sci. Lett., 171, 411-424, doi:10.1016/S0012821X(99)00169-7.

Faure, G., P. M. Hurley, and J. L. Powell (1965), The isotopic composition of strontium in surface water from the North Atlantic Ocean, Geochim. Cosmochim. Acta, 29, 209-220, doi:10.1016/0016-7037(65)90018-9.

Frank, M. (2002), Radiogenic isotopes: Tracers of past ocean circulation and erosional input, Rev. Geophys., 40(1), 1001, doi:10.1029/2000RG000094.

Fujiwara, T., J. Lin, T. Matsumoto, P. B. Kelemen, B. E. Tucholke, and J. F. Casey (2003), Crustal Evolution of the Mid-Atlantic Ridge near the Fifteen-Twenty Fracture Zone in the last $5 \mathrm{Ma}$, Geochem. Geophys. Geosyst., 4(3), 1024, doi:10.1029/2002GC000364.

Gablina, I. F., N. N. Mozgova, Y. S. Borodaev, T. V. Stepanova, G. A. Cherkashev, and M. I. Il'in (2000), Copper sulfide associations in recent oceanic ores of the Logatchev hydrothermal field (Mid-Atlantic Ridge, $14^{\circ} 45^{\prime} \mathrm{N}$ ), Geol. Ore Deposits, 42, 296-316.

Garbe-Schönberg, C.-D. (1993), Simultaneous determination of thirty-seven trace elements in twenty-eight international rock standards by ICP-MS, Geostand. Newsl., 17, 81-97, doi:10.1111/j.1751-908X.1993.tb00122.x.

Gebruk, A. V., P. Chevaldonné, T. Shank, R. A. Lutz, and R. C. Vrijenhoek (2000), Deep-sea hydrothermal vent communities of the Logatchev area $\left(14^{\circ} 45^{\prime} \mathrm{N}\right.$, Mid-Atlantic Ridge): Diverse biotopes and high biomass, J. Mar. Biol. Assoc. U. K., 80, 383-393, doi:10.1017/S0025315499002088.

Godard, M., J.-L. Bodinier, and G. Vasseur (1995), Effects of mineralogical reactions on trace element redistributions in mantle rocks during percolation processes: A chromatographic approach, Earth Planet. Sci. Lett., 133, 449-461, doi:10.1016/0012-821X(95)00104-K.

Godard, M., Y. Lagabrielle, O. Alard, and J. Harvey (2008), Geochemistry of the highly depleted peridotites drilled at ODP Sites 1272 and 1274 (Fifteen-Twenty Fracture Zone, Mid-Atlantic Ridge): Implications for mantle dynamics beneath a slow spreading ridge, Earth Planet. Sci. Lett., 267, 410-425, doi:10.1016/j.epsl.2007.11.058.

Govindaraju, K. (1994), Compilation of working values and descriptions for 383 geostandards, Geostand. Newsl., 18, $1-158$.

Hamilton, E. I. (1966), The isotopic composition of strontium in Atlantic Ocean water, Earth Planet. Sci. Lett., 1, 435-436, doi:10.1016/0012-821X(66)90040-9.

Hart, R. A., A. J. Erlank, and E. J. D. Kable (1974), Sea floor basalt alteration: Some chemical and $\mathrm{Sr}$ isotopic effects, Contrib. Mineral. Petrol., 44, 219-230.

Humphris, S. E., and G. Thompson (1983), Geochemistry of rare earth elements in basalts from the Walvis Ridge:
Implications for its origin and evolution, Earth Planet. Sci. Lett., 66, 223-242, doi:10.1016/0012-821X(83)90138-3.

Humphris, S. E., M. Halbach, and K. Juniper (2003), Lowtemperature alteration-Fluxes and mineralization, in Dahlem Workshop Report 89-Energy and Mass Transfer in Marine Hydrothermal Systems, edited by P. E. Halbach, V. Tunnicliffe, and J. R. Hein, pp. 163-182, Dahlem Univ. Press, Berlin.

Jochum, K. P., U. Nohl, K. Herwig, E. Lammel, B. Stoll, and A. W. Hofmann (2005), GeoReM: A new geochemical database for reference materials and isotopic standards, Geostand. Geoanal. Res., 29, 333-338, doi:10.1111/j.1751908X.2005.tb00904.x.

Kelemen, P. B., E. Kikawa, D. J. Miller, and the Shipboard Scientific Party (2007), Leg 209 Summary: Processes in a 20-km-thick conductive boundary layer beneath the MidAtlantic Ridge, $14^{\circ}-16^{\circ} \mathrm{N}$, Proc. Ocean Drill. Program Sci. Results, 209, 1-33.

Kimball, K. L., and D. C. Gerlach (1986), Sr isotopic constraints on hydrothermal alteration of ultramafic rocks in two oceanic fracture zones from the South Atlantic Ocean, Earth Planet. Sci. Lett., 78, 177-188, doi:10.1016/0012821X(86)90059-2.

Klein, F., W. Bach, N. Jöns, T. McCollom, B. Moskowitz, and T. Berquó (2009), Iron partitioning and hydrogen generation during serpentinization of abyssal peridotites from $15^{\circ} \mathrm{N}$ on the Mid-Atlantic Ridge, Geochim. Cosmochim. Acta, 73(22), 6868-6893, doi:10.1016/j.gca.2009.08.021.

Lackschewitz, K. S., C. W. Devey, P. Stoffers, R. Botz, A. Eisenhauer, M. Kummetz, M. Schmidt, and A. Singer (2004), Mineralogical, geochemical and isotopic characteristics of hydrothermal alteration processes in the active, submarine, felsic-hosted PACMANUS field, Manus Basin, Papua New Guinea, Geochim. Cosmochim. Acta, 68, 4405-4427, doi:10.1016/j.gca.2004.04.016.

Ludden, J. N., and G. Thompson (1979), An evaluation of the behaviour of the rare earth elements during the weathering of sea-floor basalt, Earth Planet. Sci. Lett., 43, 85-92, doi:10.1016/0012-821X(79)90157-2.

McDonough, W. F., and S.-S. Sun (1995), The composition of the Earth, Chem. Geol., 120, 223-253, doi:10.1016/00092541(94)00140-4.

Mehra, O. P., and M. L. Jackson (1958), Iron oxide removal from soils and clays by dithionite-citrate system buffered with sodium bicarbonate, Clays Clay Miner., 7, 317-327, doi:10.1346/CCMN.1958.0070122.

Mével, C. (2003), Serpentinization of abyssal peridotites at mid-ocean ridges, $C$. $R$. Geosci., 335, 825-852, doi:10.1016/j.crte.2003.08.006.

Michael, P. J., et al. (2003), Magmatic and amagmatic seafloor generation at the ultraslow-spreading Gakkel ridge, Arctic Ocean, Nature, 423, 956-961, doi:10.1038/nature01704.

Moore, D. M., and R. C. Reynolds (1989), X-Ray Diffraction and the Identification and Analysis of Clay Minerals, Oxford Univ. Press, Oxford, U. K.

Négrel, P., C. Guerrot, A. Cocherie, M. Azaroual, M. Brach, and C. Fouillac (2000), Rare earth elements, neodymium and strontium isotopic systematics in mineral waters: Evidence from the Massif Central, France, Appl. Geochem., 15, 1345-1367, doi:10.1016/S0883-2927(00)00008-1.

Niu, Y. (2004), Bulk-rock major and trace element compositions of abyssal peridotites: Implications for mantle melting, melt extraction and post-melting processes beneath mid-ocean ridges, J. Petrol., 45, 2423-2458, doi:10.1093/petrology/ egh068. 
Palmer, M. R., and J. M. Edmond (1989), The strontium isotope budget of the modern ocean, Earth Planet. Sci. Lett., 92, 11-26, doi:10.1016/0012-821X(89)90017-4.

Paulick, H., W. Bach, M. Godard, J. C. M. De Hoog, G. Suhr, and J. Harvey (2006), Geochemistry of abyssal peridotites (Mid-Atlantic Ridge, $15^{\circ} 20^{\prime} \mathrm{N}$, ODP Leg 209), Implications for fluid/rock interaction in slow spreading environments, Chem. Geol., 234, 179-210, doi:10.1016/j.chemgeo. 2006.04.011.

Petersen, S., et al. (2009), The geological setting of the ultramafic-hosted Logatchev hydrothermal field $\left(14^{\circ} 45^{\prime} \mathrm{N}\right.$, MAR) and its influence on massive sulphide formation, Lithos, 112(1-2), 40-56, doi:10.1016/j.lithos.2009.02.008.

Piccardo, G. B., O. Müntener, A. Zanetti, and T. Pettke (2003), Ophiolitic pridotites of the Alpine-Apennine system: Mantle processes and geodynamic relevance, Int. Geol. Rev., 40(11), 1119-1159.

Poitrasson, F., C. Pin, and J.-L. Duthou (1995), Hydrothermal remobilization of rare earth elements and its effect on $\mathrm{Nd}$ isotopes in rhyolite and granite, Earth Planet. Sci. Lett., 130, 1-11, doi:10.1016/0012-821X(94)00257-Y.

Rama Murthy, V., and E. Beiser (1968), Strontium isotopes in ocean water and marine sediments, Geochim. Cosmochim. Acta, 32, 1121-1126, doi:10.1016/0016-7037(68)90111-7.

Rona, P. A., L. Widenfalk, and K. Boström (1987), Serpentinized ultramafics and hydrothermal activity at the MidAtlantic Ridge crest near $15^{\circ} \mathrm{N}$, J. Geophys. Res., 92, 1417-1427, doi:10.1029/JB092iB02p01417.

Salters, V. J. M., and A. Stracke (2004), Composition of the depleted mantle, Geochem. Geophys. Geosyst., 5, Q05B07, doi:10.1029/2003GC000597.

Savin, S. M., and M. Lee (1988), Isotopic studies of phyllosilicates, in Hydrous Phyllosilicates (Exclusive of Micas), edited by S. W. Bailey, 189-223, Mineral. Soc. of Am., Washington D. C.

Schmidt, K., A. Koschinsky, D. Garbe-Schönberg, L. M. De Carvalho, and R. Seifert (2007), Geochemistry of hydrothermal fluids from the ultramafic-hosted Logatchev hydrothermal field, $15^{\circ} \mathrm{N}$ on the Mid-Atlantic Ridge: Temporal and spatial investigation, Chem. Geol., 242, 1-21, doi:10.1016/ j.chemgeo.2007.01.023.

Schmidt, K., D. Garbe-Schönberg, A. Koschinsky, H. Strauss, C. L. Jost, V. Klevenz, and P. Königer (2011), Fluid elemental and stable isotope composition of the Nibelungen hydrothermal field ( $8^{\circ} 18^{\prime} \mathrm{S}$, Mid-Atlantic Ridge): Constraints on fluid-rock interaction in heterogeneous lithosphere, Chem. Geol., 280(1-2), 1-18, doi:10.1016/j.chemgeo.2010.07.008.

Seewald, J. S., and W. E. Seyfried Jr. (1990), The effect of temperature on metal mobility in subseafloor hydrothermal systems: Constraints from basalt alteration experiments, Earth Planet. Sci. Lett., 101, 388-403, doi:10.1016/0012821X(90)90168-W.

Seyler, M., and E. Bonatti (1997), Regional-scale melt-rock interaction in lherzolitic mantle in the Romanche Fracture Zone (Atlantic Ocean), Earth Planet. Sci. Lett., 146, 273-287, doi:10.1016/S0012-821X(96)00220-8.

Seyler, M., J. P. Lorand, H. J. B. Dick, and M. Drouin (2007), Pervasive melt percolation reactions in ultra-depleted refractory harzburgites at the Mid-Atlantic Ridge, $15^{\circ} 2^{\prime} \mathrm{N}$ : ODP
Hole 1274A, Contrib. Mineral. Petrol., 153, 303-319, doi:10.1007/s00410-006-0148-6.

Sharp, Z. D., and D. L. Kirschner (1994), Quartz-calcite oxygen isotope thermometry: A calibration based on natural isotopic variations, Geochim. Cosmochim. Acta, 58, 4491-4501, doi:10.1016/0016-7037(94)90350-6.

Smith, D. K., J. Escartín, H. Schouten, and J. R. Cann (2008), Fault rotation and core complex formation: Significant processes in seafloor formation at slow-spreading mid-ocean ridges (Mid-Atlantic Ridge, $13^{\circ}-15^{\circ} \mathrm{N}$ ), Geochem. Geophys. Geosyst., 9, Q03003, doi:10.1029/2007GC001699.

Snow, J. E., and H. J. B. Dick (1995), Pervasive magnesium loss by marine weathering of peridotite, Geochim. Cosmochim. Acta, 59, 4219-4235, doi:10.1016/0016-7037(95)00239-V.

Snow, J. S., S. R. Hart, and H. J. B. Dick (1993), Orphan Strontium-87 in abyssal peridotites: Daddy was a granite, Science, 262, 1861-1863, doi:10.1126/science.262.5141.1861.

Stein, C., and S. Stein (1994), Constraints on hydrothermal heat flux through the oceanic lithosphere from global heat flow, J. Geophys. Res., 99, 3081-3095, doi:10.1029/93JB02222.

Suhr, G., P. Kelemen, and H. Paulick (2008), Microstructures in Hole 1274A peridotites, ODP Leg 209, Mid-Atlantic Ridge: Tracking the fate of melts percolating in peridotite as the lithosphere is intercepted, Geochem. Geophys. Geosyst., 9, Q03012, doi:10.1029/2007GC001726.

Teagle, D. A. H., J. C. Alt, H. Chiba, and A. N. Halliday (1998), Dissecting an active hydrothermal deposit: The strontium and oxygen isotopic anatomy of the TAG hydrothermal mound-anhydrite, Proc. Ocean Drill. Program Sci. Results, 158, 129-141.

Tucholke, B. E., and J. Lin (1994), A geological model for the structure of ridge segments in slow spreading ocean crust, J. Geophys. Res., 99, 11,937-11,958, doi:10.1029/ 94JB00338.

Verma, S. P. (1992), Seawater alteration effects on REE, K, $\mathrm{Rb}, \mathrm{Cs}, \mathrm{Sr}, \mathrm{U}, \mathrm{Th}, \mathrm{Pb}$ and $\mathrm{Sr}-\mathrm{Nd}-\mathrm{Pb}$ isotope systematics of Mid-Ocean Ridge Basalt, Geochem. J., 26, 159-177, doi:10.2343/geochemj.26.159.

Vils, F., L. Pelletier, A. Kalt, O. Müntener, and T. Ludwig (2008), The lithium, boron and beryllium content of serpentinized peridotites from ODP Leg 209 (Sites 1272A and 1274A): Implications for lithium and boron budgets of oceanic lithosphere, Geochim. Cosmochim. Acta, 72, 5475-5504, doi:10.1016/j.gca.2008.08.005.

Watson, E. B. (2004), A conceptual model for near-surface kinetic controls on the trace-element and stable isotope composition of abiogenic calcite crystals, Geochim. Cosmochim. Acta, 68, 1473-1488, doi:10.1016/j.gca.2003.10.003.

White, W. M., and J. Patchett (1984), Hf-Nd-Sr isotopes and incompatible element abundance in island arcs-Implications for magma origins and crust-mantle evolution, Earth Planet. Sci. Lett., 67, 167-185, doi:10.1016/0012-821X(84)90112-2.

Williams, L. B., and R. L. Hervig (2005), Lithium and boron isotopes in illite-smectite: The importance of crystal size, Geochim. Cosmochim. Acta, 69, 5705-5716, doi:10.1016/ j.gca.2005.08.005

Zheng, Y.-F. (1993), Calculation of oxygen isotope fractionation in hydroxyl-bearing silicates, Earth Planet. Sci. Lett., 120, 247-263, doi:10.1016/0012-821X(93)90243-3. 